\title{
Chemically intractable no more: in vivo incorporation of "click"-ready fatty acids into poly-[(R)-3-hydroxyalkanoates] in Escherichia coli
}

Atahualpa Pinto ${ }^{2}$, Jessica H. Ciesla ${ }^{2}$, Adriana Palucci ${ }^{2}$, Bradley P. Sutliff ${ }^{2,5}$, and Christopher T. Nomura ${ }^{1,2,3,4,5 *}$

${ }^{1}$ Hubei Collaborative Center for Green Transformation of Bio-Resources, College of Life Sciences, Hubei University, Wuhan 430062, PR China, ${ }^{2}$ Department of Chemistry, ${ }^{3}$ Michael M. Szwarc Polymer Research Institute, and ${ }^{4}$ Center for Applied Microbiology, State University of New York - College of Environmental Science and Forestry (SUNY-ESF), Jahn Laboratory, 1 Forestry Drive, Syracuse, New York 13210, United States, ${ }^{5}$ Syracuse Biomaterials Institute, Syracuse University, Syracuse, New York 13244, United States

\section{SUPPORTING INFORMATION}

TABLE OF CONTENTS

PAGE

General Experimental

$\begin{array}{lr}\text { Bacterial Strains, Plasmids, and Growth Medium } & S 2\end{array}$

$\begin{array}{lr}\text { Experimental Procedures } & S 3\end{array}$

$\begin{array}{ll}\text { Synthesis of Azidofatty Acids } & S 3\end{array}$

$\begin{array}{ll}\text { PHA Production and Characterization } & S 8\end{array}$

$\begin{array}{ll}\text { Fermentation Conditions } & S 8\end{array}$

$\begin{array}{ll}\text { Isolation and Purification } & S 8\end{array}$

$\begin{array}{ll}\text { Molecular Weight Determination } & S 8\end{array}$

$\begin{array}{ll}\text { Thermal Analysis } & S 9\end{array}$

$\begin{array}{ll}\text { Infrared Spectroscopy } & S 9\end{array}$

$\begin{array}{lr}\text { References } & S 9\end{array}$

$\begin{array}{ll}\text { NMR Spectra } & S 11\end{array}$

$\begin{array}{ll}\text { Synthetic Intermediates } & \text { S11 }\end{array}$

Assignment and Structural Confirmation of $\mathrm{PHODN}_{3}-\mathrm{BCN}-\mathrm{OH} \quad S 18$

$\begin{array}{ll}\text { Spectra of Azido-PHA Homopolymers } & S 22\end{array}$

Sample Spectra for the Construction of Calibration Curves $\quad S 24$

$\begin{array}{ll}\text { Calibration Curves } & S 28\end{array}$

$\begin{array}{lr}\text { Isolated Polymer Yields } & S 30\end{array}$

$\begin{array}{ll}\text { GPC Results } & S 31\end{array}$

$\begin{array}{lr}\text { FT-IR Spectra } & S 33\end{array}$

$\begin{array}{ll}\text { Thermal Properties } & S 36\end{array}$

$\begin{array}{ll}\text { DSC Thermograms } & S 37\end{array}$

$\begin{array}{lr}\text { TGA Thermograms } & S 39\end{array}$ 


\section{General Experimental}

Chemical reactions were carried out under argon atmosphere with dry solvents, and oven-dried glassware under anhydrous conditions unless specified otherwise. Acetone (Fisher, ACS grade), acetonitrile (MeCN, Sigma-Aldrich, ACS grade), chloroform $\left(\mathrm{CHCl}_{3}\right.$, Fisher, Optima grade), methanol (MeOH, Pharmco-AAPER, HPLC grade), dichloromethane (DCM, Fisher, ACS grade), 2-propanol ( $\mathrm{PrOH}$, Pharmco-AAPER, ACS grade), diethyl ether $\left(\mathrm{Et}_{2} \mathrm{O}\right.$, Pharmco-AAPER, ACS grade, BHT stabilized), toluene (MePh, Pharmco-AAPER, ACS grade), and dimethylformamide (DMF, Acros, SPPS grade) were purchased and employed without further purification. Solvents such as ethyl acetate (EtOAc, Fisher, ACS grade) and hexanes (Fisher, ACS grade), employed in workup and chromatographic separations, were used without further purification, unless otherwise stated. Brine refers to a saturated aqueous solution of sodium chloride ( $\mathrm{NaCl}$, Sigma-Aldrich). Magnesium sulfate (J.T. Baker), sodium hydroxide (Fisher), glacial acetic acid (AcOH, Pharmco-AAPER, reagent grade), hydrobromic acid (HBr, 47-49\%, Alfa Aesar), 10-bromodecanoic acid (Fisher), 1,8-octanediol (Acros), 1,12dodecanediol (Fisher), $\mathrm{N}$-methylmorpholine $\mathrm{N}$-oxide (NMO, Acros), tetrapropylammonium perruthenate (TPAP, Acros), (1R,8S,9s)-bicyclo[6.1.0]non-4-yn-9-ylmethanol (11, BCN-OH, Sigma-Aldrich), and sodium azide (Acros) were purchased at the highest commercial quality and used without further purification, unless otherwise stated. Yields refer to chromatographically and spectroscopically $\left({ }^{1} \mathrm{H}\right.$ and $\left.{ }^{13} \mathrm{C} \mathrm{NMR}\right)$ homogeneous materials, unless otherwise stated.

Reactions were monitored by analytical thin-layer chromatography (TLC) and carried out on $250 \mu \mathrm{m}$ E. Merck silica gel plates (60F-254) using UV light as the visualizing agent and/or an acidic solution of $p$ anisaldehyde (PA) and heat as developing agents. Flash column chromatography was performed with SiliCycle SiliaFlash F60 silica gel (pore size $60 \AA$, particle size $40-63 \mu \mathrm{m}$ ).

NMR spectra were recorded on Bruker AVANCE III HD $800 \mathrm{MHz}$ or Bruker AVANCE III $600 \mathrm{MHz}$ instruments, and were calibrated using residual undeuterated solvents as internal reference (chloroform, $\delta=7.26$ ppm, ${ }^{1} \mathrm{H}$ NMR; $77.00 \mathrm{ppm},{ }^{13} \mathrm{C} \mathrm{NMR}$ ). Chemical shifts $(\delta)$ are reported in parts per million (ppm); NMR peak multiplicities are denoted by the following abbreviations: $\mathrm{s}=$ singlet, $\mathrm{d}=$ doublet, $\mathrm{t}=$ triplet, $\mathrm{q}=$ quartet, $\mathrm{p}=$ pentet, $\mathrm{dd}=$ doublet of doublets, $\mathrm{dt}=$ doublet of triplets, $\mathrm{m}=$ multiplet, $\mathrm{br}=$ broad; coupling constants $(J)$ are reported in Hertz (Hz). Spectra were processed with Bruker TopSpin v3.5pI2.

\section{Bacterial Strains, Plasmids, and Growth Medium}

E. coli LSBJ carrying the plasmid pBBR-C1J4SII, previously generated in our lab, ${ }^{1}$ was selectively grown in Lennox Broth (LB, BD Difco ${ }^{\mathrm{TM}}$ ) liquid medium (composition per liter: $10 \mathrm{~g}$ tryptone, $5 \mathrm{~g}$ yeast extract, and $5 \mathrm{~g}$ sodium chloride) while the antibiotic kanamycin sulfate was purchased from Fisher Scientific. Growth media

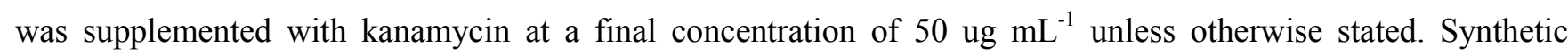
azidofatty acids and sodium octanoate (Sigma-Aldrich) were employed as cosubstrates for PHA biosynthesis to a total fatty acid concentration of $10 \mathrm{mM}$. To aid dissolution of fatty acids, the surfactant Brij-35 (Sigma-Aldrich) was added to flasks at a $4.0 \mathrm{~g} \mathrm{~L}^{-1}$ final concentration. HPLC grade methanol and chloroform were used in sample pretreatment, extraction, and purification of polymers from dried bacterial cells. 


\section{Experimental Procedures}

\section{Synthesis of Azidofatty Acids}
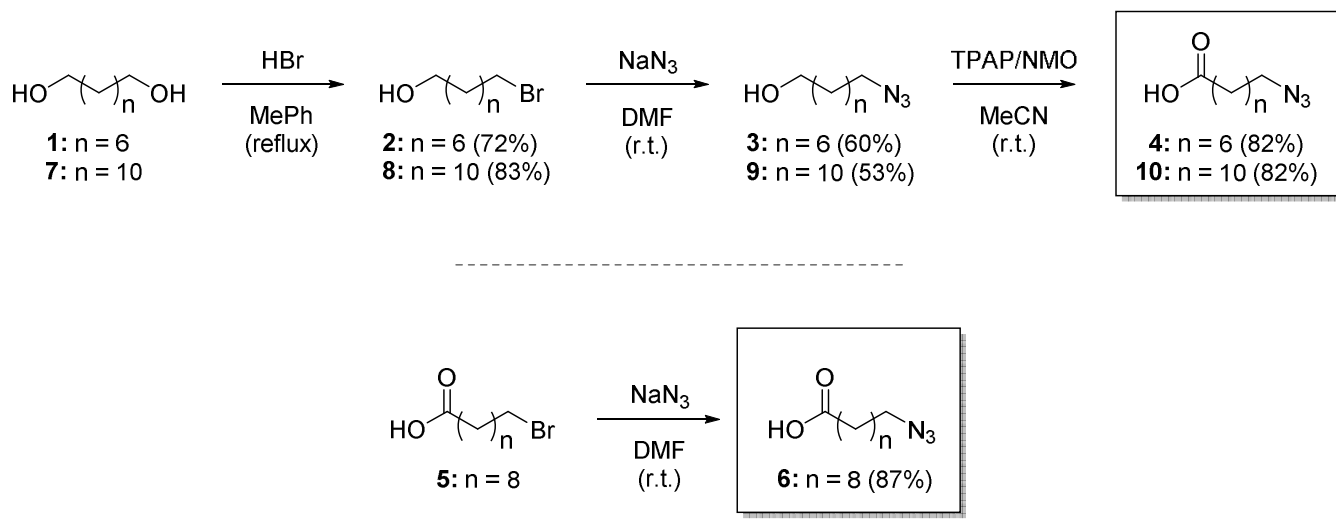

\section{8-Bromo-1-octanol (2)}

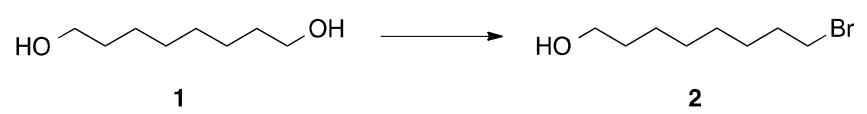

The monobromination was performed as described by Chong et al. with minor modifications. ${ }^{2}$ Briefly, in a round bottom flask, diol $1(8.16 \mathrm{~g}, 55.8 \mathrm{mmol})$ and $\mathrm{HBr}(8.00 \mathrm{~mL}, 66.4 \mathrm{mmol}, 1.19$ equiv) were refluxed in toluene $(125 \mathrm{~mL})$ for 24 hours. The reaction was quenched with $\mathrm{NaOH}(100 \mathrm{~mL}, 1 \mathrm{M})$ and extracted with $\mathrm{Et}_{2} \mathrm{O}(3$ $\times 100 \mathrm{~mL})$. The organic extracts were combined, dried with brine $(100 \mathrm{~mL})$ and $\mathrm{MgSO}_{4}$, and concentrated in vacuo.

To purify, excess toluene was first removed via flash column chromatography using $100 \%$ hexanes, after which 2 was collected by increasing the solvent system's polarity to $100 \%$ ethyl acetate. Pure fractions were concentrated in vacuo to yield pure 2 as a light yellow oil (9.90 g, $47.3 \mathrm{mmol}, 72 \%)$. The spectroscopic data for 2 is identical to that previously reported by Becker et al. ${ }^{3}$

Analytical Data for 2

M.W.: $209.13 \mathrm{~g} / \mathrm{mol}$

TLC: $\quad R_{f} 0.38\left(30 \%\right.$ EtOAc/Hexane) $\left[\mathrm{SiO}_{2}, \mathrm{PA}\right]$

${ }^{1} \mathrm{H}$ NMR: $\quad\left(600 \mathrm{MHz}, \mathrm{CDCl}_{3}\right)$ :

$\delta=3.62(\mathrm{t}, J=7.2 \mathrm{~Hz}, 2 \mathrm{H}), 3.39(\mathrm{t}, J=6.6 \mathrm{~Hz}, 2 \mathrm{H}), 1.84(\mathrm{p}, J=7.2 \mathrm{~Hz}, 2 \mathrm{H}), 1.55$ (p,

$J=7.2 \mathrm{~Hz}, 2 \mathrm{H}), 1.42$ (q, $J=6.6 \mathrm{~Hz}, 2 \mathrm{H}), 1.33$ (m, $6 \mathrm{H}) \mathrm{ppm}$

${ }^{13} \mathrm{C} \mathrm{NMR} \quad\left(150 \mathrm{MHz}, \mathrm{CDCl}_{3}\right)$ :

$\delta=62.91,33.92,32.74,32.67,29.17,28.67,28.05,25.60 \mathrm{ppm}$ 


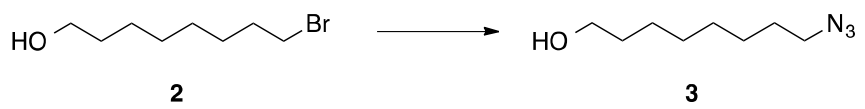

Followed the procedure outlined by Ardes-Guisot et al. with minor modifications. ${ }^{4}$ In a round bottom flask, 8 bromo-1-octanol (2, $9.90 \mathrm{~g}, 47.3 \mathrm{mmol})$ and sodium azide $(6.16 \mathrm{~g}, 94.7 \mathrm{mmol}, 2.0$ equiv) were dissolved in DMF $(47.3 \mathrm{~mL})$, and stirred at r.t. for $52 \mathrm{~h}$. After completion, the reaction was diluted with water $(20 \mathrm{~mL})$, and extracted with DCM $(5 \times 10 \mathrm{~mL})$. The organic layers were combined and washed with brine $(5 \times 10 \mathrm{~mL})$, dried over $\mathrm{MgSO}_{4}$ and concentrated in vacuo. The crude product was purified by flash column chromatography $\left(\mathrm{SiO}_{2}\right.$, $20 \%$ acetone/hexanes), and concentrated in vacuo to yield 3 as a yellow oil (4.85 g, $28.3 \mathrm{mmol}, 60 \%$ ). The spectroscopic data obtained for $\mathbf{3}$ is as previously reported by Cao et al. ${ }^{5}$

Analytical Data for 3

M.W.: $171.24 \mathrm{~g} / \mathrm{mol}$

TLC: $\quad R_{f} 0.38\left(30 \%\right.$ EtOAc/Hexane) $\left[\mathrm{SiO}_{2}, \mathrm{PA}\right]$

${ }^{1} \mathrm{H}$ NMR: $\quad\left(600 \mathrm{MHz}, \mathrm{CDCl}_{3}\right)$ :

$\delta=3.64(\mathrm{t}, J=6.6 \mathrm{~Hz}, 2 \mathrm{H}), 3.25(\mathrm{t}, J=7.2 \mathrm{~Hz}, 2 \mathrm{H}), 1.58(\mathrm{~m}, 5 \mathrm{H}), 1.35(\mathrm{~m}, 9 \mathrm{H}), 1.41$

$(\mathrm{m}, 2 \mathrm{H}), 1.31(\mathrm{~m}, 18 \mathrm{H}) \mathrm{ppm}$

${ }^{13} \mathrm{C} \mathrm{NMR} \quad\left(150 \mathrm{MHz}, \mathrm{CDCl}_{3}\right)$ :

$\delta=63.00,51.50,32.71,29.23,29.10,28.80,26.62,25.62 \mathrm{ppm}$

\section{8-Azidooctanoic acid (4)}

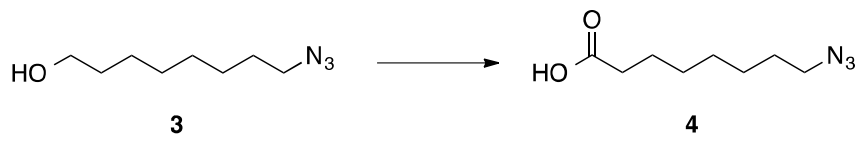

The following procedure was performed as described by Schmidt et al. with a few modifications. ${ }^{6}$ In a round bottom flask, NMO (9.64 g, $82.3 \mathrm{mmol}, 12.0$ equiv) and 3 (1.17 g, $6.86 \mathrm{mmol})$ were dissolved in $\mathrm{MeCN}(27 \mathrm{~mL})$ while stirring at r.t. TPAP ( $241 \mathrm{mg}, 0.686 \mathrm{mmol}, 0.10$ equiv) was added to mixture, and reaction was allowed to proceed for $24 \mathrm{~h}$ while monitoring its completion by TLC.

The reaction was quenched with excess $i \mathrm{PrOH}$ and concentrated in vacuo. To remove the ruthenium catalyst, the crude was dissolved and filtered through a plug of silica (1\% AcOH/EtOAc), and following solvent evaporation, the product was purified by flash column chromatography $\left(\mathrm{SiO}_{2}, 30 \% \mathrm{EtOAc} /\right.$ hexanes containing $1 \% \mathrm{AcOH})$ and concentrated in vacuo to yield 4 as a yellow oil $(1.04 \mathrm{~g}, 5.61 \mathrm{mmol}, 82 \%)$. The spectroscopic data for $\mathbf{4}$ is as previously described in Colombano et al. ${ }^{7}$

Analytical Data for 4

M.W.: $185.23 \mathrm{~g} / \mathrm{mol}$

TLC: $\quad R_{f} 0.40\left(30 \%\right.$ EtOAc/Hexane) $\left[\mathrm{SiO}_{2}, \mathrm{PA}\right]$

${ }^{1} \mathrm{H}$ NMR: $\quad\left(600 \mathrm{MHz}, \mathrm{CDCl}_{3}\right)$ :

$$
\delta=3.25(\mathrm{t}, J=7.2 \mathrm{~Hz}, 2 \mathrm{H}), 3.34(\mathrm{t}, J=7.2 \mathrm{~Hz}, 2 \mathrm{H}), 1.63(\mathrm{p}, J=7.2 \mathrm{~Hz}, 2 \mathrm{H}), 1.59 \text { (p, } J
$$




$$
=7.2 \mathrm{~Hz}, 2 \mathrm{H}), 1.36(\mathrm{~m}, 6 \mathrm{H}) \mathrm{ppm}
$$

${ }^{13} \mathrm{C} \mathrm{NMR} \quad\left(150 \mathrm{MHz}, \mathrm{CDCl}_{3}\right)$ :

$$
\delta=180.13,51.38,33.95,28.82,28.72,26.47,24.48 \mathrm{ppm}
$$

\section{0-Azidodecanoic acid (6)}

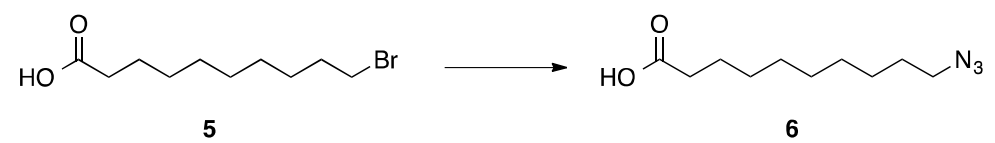

The following procedure was performed as described previously by Nagarajan et al. with slight modifications. $^{8}$ 10-Bromodecanoic acid $(5,2.40 \mathrm{~g}, 9.0 \mathrm{mmol})$ and sodium azide $(0.878 \mathrm{~g}, 13.5 \mathrm{mmol}, 1.5$ equiv) were dissolved in $50 \mathrm{~mL}$ DMF. The reaction was heated to $60^{\circ} \mathrm{C}$ and stirred overnight under argon.

After cooling to r.t. the reaction was diluted with ethyl acetate (EtOAc, $40 \mathrm{~mL})$ and water $(40 \mathrm{~mL})$. Extracted with EtOAc $(3 \times 40 \mathrm{~mL})$ and the organic layers were combined, dried with brine $(2 \times 40 \mathrm{~mL})$, and magnesium sulfate. The solvent was removed in vacuo and the crude purified by flash column chromatography $\left(\mathrm{SiO}_{2}, 30 \%\right.$ EtOAc/hexanes). After evaporation of the solvent under low pressure, 6 was obtained as a clear oil (1.67 g, 7.8 mmol, $87 \%$ yield). The spectroscopic data for 6 is identical to that previously reported by Nagarajan et al. ${ }^{8}$

Analytical data for $6^{\mathrm{a}}$

M.W.: 213.28

TLC: $\quad R_{f} 0.44(30 \%$ EtOAc/hexanes $)\left[\mathrm{SiO}_{2}, \mathrm{PA}\right]$

${ }^{1} \mathrm{H}$ NMR: $\quad\left(600 \mathrm{MHz}, \mathrm{CDCl}_{3}\right)$

$\delta 3.24(\mathrm{t}, J=7.2 \mathrm{~Hz}, 2 \mathrm{H}), 2.34(\mathrm{t}, J=7.2 \mathrm{~Hz}, 2 \mathrm{H}), 1.63$ (p, $J=7.2 \mathrm{~Hz}, 2 \mathrm{H}), 1.59$ (p, $J$

$=7.2 \mathrm{~Hz}, 2 \mathrm{H}), 1.36-1.25(\mathrm{~m}, 10 \mathrm{H}) \mathrm{ppm}$

${ }^{13} \mathrm{C} \mathrm{NMR:} \quad\left(150 \mathrm{MHz}, \mathrm{CDCl}_{3}\right)$

$\delta 180.30,51.42,34.02,29.18,29.04,29.00,28.93,28.77,28.01,26.72,26.62,24.57$

ppm

\section{2-Bromo-1-dodecanol (8)}

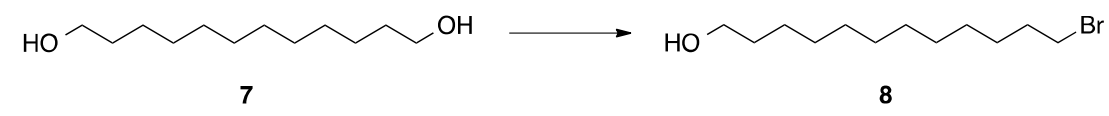

The monobromination was performed as described by Chong, et al. with minor modifications. ${ }^{2}$ In a round bottom flask, 1,12-dodecanediol (7, $5.08 \mathrm{~g}, 24.8 \mathrm{mmol})$ and $\mathrm{HBr}(3.32 \mathrm{~mL}, 1.17$ equiv) were dissolved in toluene $(72.9 \mathrm{~mL})$, and the reaction refluxed for 24 hours while monitoring by TLC. The reaction was quenched with $\mathrm{NaOH}(100 \mathrm{~mL}, 1 \mathrm{M})$ and extracted with $\mathrm{Et}_{2} \mathrm{O}(3 \times 50 \mathrm{~mL})$. The organic layers were combined, dried with brine $(100 \mathrm{~mL})$ and $\mathrm{MgSO}_{4}$ before concentrating in vacuo.

Toluene was removed via flash column chromatography $\left(\mathrm{SiO}_{2}, 100 \%\right.$ hexanes) and, once removed, 8 was eluted by increasing the solvent system to $100 \%$ EtOAc. Pure fractions were concentrated in vacuo to yield $\mathbf{8}$ as light brown crystals $(5.47 \mathrm{~g}, 20.6 \mathrm{mmol}, 83 \%)$. The spectroscopic data for $\mathbf{8}$ is identical to that previously reported by Shorey et al. ${ }^{9}$ 
Analytical data for $\mathbf{8}$

M.W.: $\quad 265.24 \mathrm{~g} / \mathrm{mol}$

TLC: $\quad R_{f} 0.48\left(30 \%\right.$ EtOAc/hexanes) $\left[\mathrm{SiO}_{2}, \mathrm{PA}\right]$

${ }^{1} \mathrm{H}$ NMR: $\quad\left(600 \mathrm{MHz}, \mathrm{CDCl}_{3}\right)$ :

$\delta=3.63(\mathrm{t}, J=6.6 \mathrm{~Hz}, 2 \mathrm{H}), 3.40(\mathrm{t}, J=6.6 \mathrm{~Hz}, 2 \mathrm{H}), 1.85(\mathrm{p}, J=13.8 \mathrm{~Hz}, 2 \mathrm{H}), 1.56(\mathrm{p}$,

$J=13.8 \mathrm{~Hz}, 2 \mathrm{H}), 1.44-1.39$ (m, $3 \mathrm{H}), 1.37-1.25$ (m, 14 H) ppm

${ }^{13} \mathrm{C} \mathrm{NMR} \quad\left(150 \mathrm{MHz}, \mathrm{CDCl}_{3}\right)$ :

$\delta=62.60,33.78,32.68,32.56,29.43,29.38,29.35,29.28,29.27,28.60,28.01,25.61$

ppm

\section{2-Azido-1-dodecanol (9)}

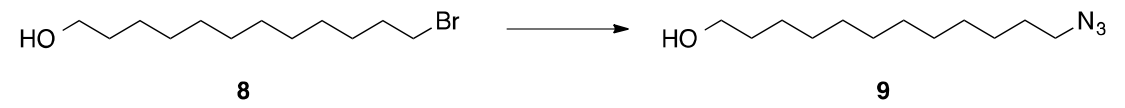

The following procedure was performed as described previously by Johnstone et al. with modifications. ${ }^{10}$ In a round bottom flask, 12-bromo-1-dodecanol $(8,4.70 \mathrm{~g}, 17.7 \mathrm{mmol})$ and sodium azide $(2.31 \mathrm{~g}, 35.4 \mathrm{mmol}, 2.0$ equiv) were dissolved in DMF $(17.7 \mathrm{~mL})$, and stirred at r.t. for $52 \mathrm{~h}$. After completion, the reaction was diluted with water $(20 \mathrm{~mL})$, and extracted with DCM $(5 \times 10 \mathrm{~mL})$. The organic layers were combined, dried with brine $(5$ $\times 10 \mathrm{~mL}$ ) and $\mathrm{MgSO}_{4}$, and concentrated in vacuo. The crude product was purified by flash column chromatography $\left(\mathrm{SiO}_{2}, 20 \%\right.$ ethyl acetate/hexanes), and concentrated in vacuo to yield $\mathbf{9}$ as a yellow oil (2.15 g, $9.46 \mathrm{mmol}, 53 \%$ ). Spectral data was in accord with the reported values by Murozuka et al. ${ }^{11}$

$\underline{\text { Analytical data for } 9}$

M.W.: $227.35 \mathrm{~g} / \mathrm{mol}$

TLC: $\quad R_{f} 0.42\left(30 \%\right.$ EtOAc/hexanes) $\left[\mathrm{SiO}_{2}, \mathrm{PA}\right]$

${ }^{1} \mathrm{H}$ NMR: $\quad\left(600 \mathrm{MHz}, \mathrm{CDCl}_{3}\right)$ :

$\delta=3.64(\mathrm{t}, J=7.2 \mathrm{~Hz}, 2 \mathrm{H}), 3.25(\mathrm{t}, J=7.8 \mathrm{~Hz}, 2 \mathrm{H}), 1.58(\mathrm{~m}, 4 \mathrm{H}), 1.32(\mathrm{~m}, 18 \mathrm{H}) \mathrm{ppm}$

${ }^{13} \mathrm{C} \mathrm{NMR} \quad\left(150 \mathrm{MHz}, \mathrm{CDCl}_{3}\right)$ :

$\delta=63.08,51.50,32.81,29.56,29.51,29.49,29.44,29.40,29.13,28.83,26.70,25.73$

ppm

\section{2-Azidododecanoic acid (10)}

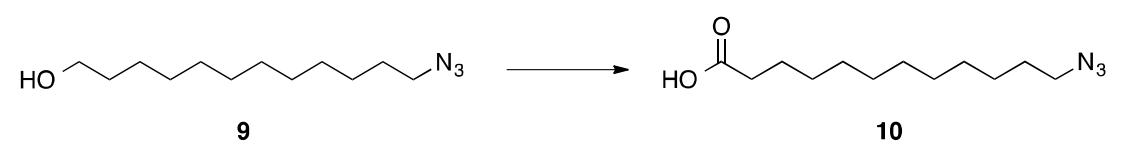

Oxidation of 9 was performed as described by Schmidt et al with modifications. ${ }^{6}$ 12-Azido-1-dodecanol (9, $1.22 \mathrm{~g}, 5.37 \mathrm{mmol}$ ) and NMO (9.64 g, $82.3 \mathrm{mmol}, 12.0$ equiv) were dissolved in $\mathrm{MeCN}$ (27 mL), followed by TPAP (241 mg, $0.69 \mathrm{mmol}, 0.13$ equiv), and the reaction was stirred for $24 \mathrm{~h}$ at r.t. The reaction was quenched 
with excess $i \mathrm{PrOH}$ and concentrated in vacuo. To remove the ruthenium catalyst, the crude was dissolved and filtered through a plug of silica $(1 \% \mathrm{AcOH} / \mathrm{EtOAc})$, and following solvent evaporation, the product was purified by flash column chromatography $\left(\mathrm{SiO}_{2}, 30 \%\right.$ EtOAc/hexanes containing $\left.1 \% \mathrm{AcOH}\right)$ and concentrated in vacuo to yield $\mathbf{1 0}$ as a pale yellow oil $(1.07 \mathrm{~g}, 4.43 \mathrm{mmol}, 82 \%)$. The spectroscopic data for $\mathbf{1 0}$ is identical to that previously reported by Hang et al. ${ }^{12}$

Analytical data for $\mathbf{1 0}$

M.W.: $241.34 \mathrm{~g} / \mathrm{mol}$

TLC: $\quad R_{f} 0.44\left(30 \%\right.$ EtOAc/hexanes) $\left[\mathrm{SiO}_{2}, \mathrm{PA}\right]$

${ }^{1} \mathrm{H}$ NMR: $\quad\left(600 \mathrm{MHz}, \mathrm{CDCl}_{3}\right)$ :

$\delta=3.25(\mathrm{t}, J=6.6 \mathrm{~Hz}, 2 \mathrm{H}), 2.34(\mathrm{t}, J=7.2 \mathrm{~Hz}, 2 \mathrm{H}), 1.63(\mathrm{p}, J=14.4 \mathrm{~Hz}, 2 \mathrm{H}), 1.59(\mathrm{p}$, $J=14.4 \mathrm{~Hz}, 2 \mathrm{H}), 1.33(\mathrm{~m}, 14 \mathrm{H}) \mathrm{ppm}$

${ }^{13} \mathrm{C} \mathrm{NMR} \quad\left(150 \mathrm{MHz}, \mathrm{CDCl}_{3}\right)$ :

$\delta=179.3,51.49,33.90,29.41(2 \mathrm{C}), 29.34,29.18,29.11,29.02,28.83,26.70,24.66 \mathrm{ppm}$

\section{PHODN $_{3}-\mathrm{BCN}-\mathrm{OH}$}

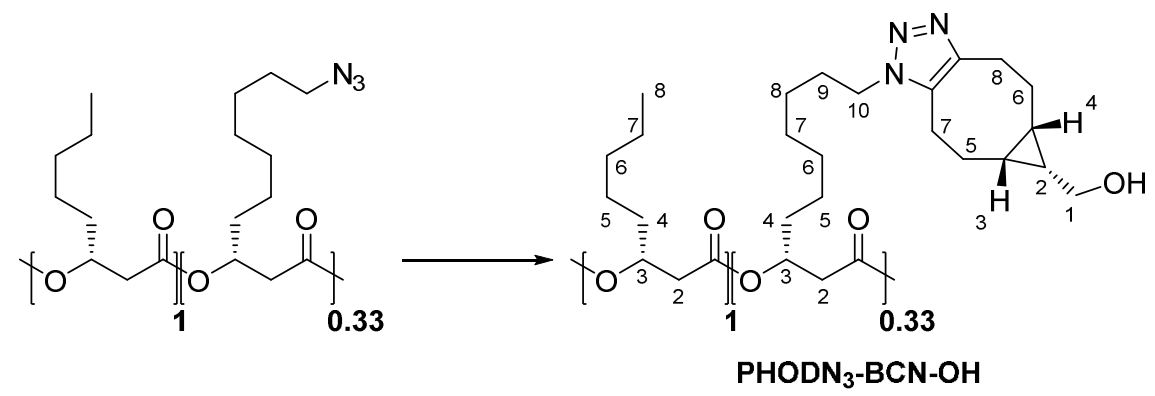

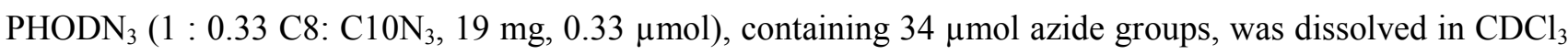
$(1.0 \mathrm{~mL})$. BCN-OH $(\mathbf{1 1}, 5.1 \mathrm{mg}, 34 \mu \mathrm{mol}, 1.0$ equiv) was added and thoroughly mixed to homogeneity, and allowed to proceed overnight at r.t. The mixture was transferred to a clean NMR tube and analyzed by collecting 1D and 2D NMR spectra.

\section{$\underline{\text { Analytical data for PHODN }} 3$-BCN-OH}

\section{${ }^{1} \mathrm{H}$ NMR: $\quad\left(600 \mathrm{MHz}, \mathrm{CDCl}_{3}\right)$ :}

$\delta=5.18-5.16\left(\right.$ br m, $\left.2 \mathrm{H}, \mathrm{C} 8-3, \mathrm{C} 10 \mathrm{~N}_{3}-3\right), 4.19$ (br t, $\left.J=7.2 \mathrm{~Hz}, 2 \mathrm{H}, \mathrm{C} 10 \mathrm{~N}_{3}-10\right), 3.76$

- 3.64 (m, $2 \mathrm{H}, \mathrm{BCN}-1$ ), 3.09 (br m, 1H, BCN-7a), 2.93 - 2.83 (br m, 2H, BCN-7b, BCN-8a), $2.69-2.65$ (br m, 1H, BCN-8b), $2.58-2.47$ (m, 4H, C8-2, C10N $3-2$ ), $2.29-$ 2.25 (m, 1H, BCN-5a), $2.24-2.19$ (br m, 1H, BCN-6a), $1.82-1.74$ (br m, 2H, C10N ${ }^{-}$ 9), $1.63-1.49$ (br m, $6 \mathrm{H}, \mathrm{C} 8-4, \mathrm{C} 10 \mathrm{~N}_{3}-4, \mathrm{BCN}-5 \mathrm{~b}, \mathrm{BCN}-6 \mathrm{~b}$ ), $1.34-1.23$ (br m, $14 \mathrm{H}$,

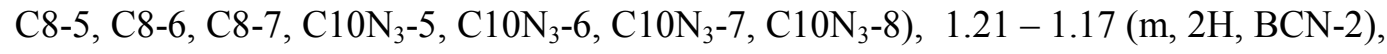
$1.08-0.96$ (m, 2H, BCN-3, BCN-4), $0.89-0.84$ (br m, 3H, C8-8) ppm 


\section{PHA Production and Characterization}

\section{Fermentation Conditions}

E. coli LSBJ was made chemically competent, transformed with the pBBR-C1J4SII plasmid following standard procedures, ${ }^{13}$ and grown on LB-kanamycin plates at $37{ }^{\circ} \mathrm{C}$ for $12-16 \mathrm{~h}$. For polymer production, as previously described, ${ }^{14}$ a single colony was used to inoculate $50 \mathrm{~mL}$ of sterile $\mathrm{LB}$ with kanamycin, and this culture was incubated at $37^{\circ} \mathrm{C}$ in an orbital shaker at $250 \mathrm{rpm}$ for $12-16 \mathrm{~h}$ (overnight). In triplicate, aliquots (1 $\mathrm{mL}$ ) of the $50 \mathrm{~mL}$ E. coli LSBJ/pBBR-C1J4SII culture were used to inoculate $100 \mathrm{~mL}$ growth media in $500 \mathrm{~mL}$ baffled shake flasks. The PHA production media contained sterile LB, kanamycin, fatty acid cosubstrates, and Brij-35 as outlined above, and was incubated at $30{ }^{\circ} \mathrm{C}$ in an orbital shaker at $250 \mathrm{rpm}$ for 48 hours.

\section{Isolation and Purification}

Cells were harvested by centrifugation $(3,452 \times g, 30 \mathrm{~min}$, r.t.). Following decantation, the pelleted cells were washed by resuspending in $35 \%(\mathrm{v} / \mathrm{v})$ ethanol $(10 \mathrm{~mL})$, collected by centrifugation, frozen at $-80{ }^{\circ} \mathrm{C}$, and lyophilized for $24 \mathrm{~h}$. Polymer was extracted from the dried cell sample after transferring into a Kimax ${ }^{\mathrm{TM}}$ screw thread tube, resuspending with $\mathrm{CHCl}_{3}(6 \mathrm{~mL})$, and heating to $100{ }^{\circ} \mathrm{C}$ for $2 \mathrm{~h}$. After cooling to room temperature, the solution was syringe filtered (PTFE, $0.45 \mu \mathrm{m}$ ) into a $20 \mathrm{~mL}$ scintillation vial, and evaporated solvent in vacuo to yield a pale yellow crude polymer sample. To purify, the crude sample was redissolved in $\mathrm{CHCl}_{3}(2 \mathrm{~mL})$ and added dropwise to a chilled $\left(-20^{\circ} \mathrm{C}\right)$, and well-stirred $\mathrm{MeOH}(10 \mathrm{~mL})$ solution. The cloudy solution was centrifuged $\left(3,452 \times g, 30 \mathrm{~min}, 4{ }^{\circ} \mathrm{C}\right)$ to pellet the polymer sample, washed by resuspending the sample after decantation with an additional $5 \mathrm{~mL}$ of $\mathrm{MeOH}$, and centrifuged $\left(3,452 \times g, 30 \mathrm{~min}, 4{ }^{\circ} \mathrm{C}\right)$. Following decantation and dissolution of the pellet with $\mathrm{CHCl}_{3}(2 \mathrm{~mL})$, the polymer solution was concentrated in a rotary evaporator, and full evaporation of residual solvent was accomplished under high vacuum overnight. Purified PHA samples were kept at $-20{ }^{\circ} \mathrm{C}$ pending further analyses.

\section{Molecular Weight Determination}

Both weight average $\left(M_{w}\right)$ and number average $\left(M_{n}\right)$ molecular weights were determined using gel permeation chromatography as described previously. ${ }^{18}$ Polymer samples were dissolved in chloroform to an approximate concentration of $1.0 \mathrm{~g} \mathrm{~L}^{-1}$ and passed through a $0.45 \mu \mathrm{m}$ PTFE syringe filter. Samples were injected at a volume of $50 \mu$ into a Shimadzu LC-20AD liquid chromatograph equipped with a Shimadzu SIL-20A autosampler, a Shimadzu CTO-20A column oven, and a Shimadzu RID-10A refractive index detector. Samples were passed through an $8 \times 50 \mathrm{~mm}$ styrenedivinylbenvene (SDV) guard column ( $5 \mu \mathrm{m}$ particles; Polymer Standards Service) and an $8 \times 300 \mathrm{~mm}$ SDV analytical column (5 $\mu \mathrm{m}$ particles; mixed bed porosity; max molecular weight 1E6 Da; Polymer Standards Service product sda083005lim). The column oven was maintained at $40^{\circ} \mathrm{C}$, and chloroform

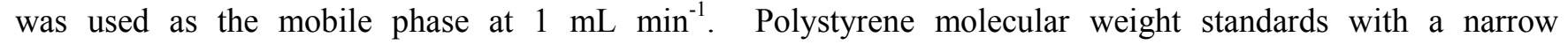
polydispersity index were employed for calibration. Analysis was performed using Shimadzu LCsolution software. 


\section{Thermal Analysis}

The decomposition temperatures $\left(T_{\mathrm{d} 1}\right.$ and $\left.T_{\mathrm{d} 2}\right)$ of extracted azido-PHA polymers were determined by thermogravimetric analysis (TGA). The melting temperatures $\left(T_{\mathrm{m}}\right)$, crystallization temperatures $\left(T_{\mathrm{c}}\right)$, and glasstransition temperatures $\left(T_{\mathrm{g}}\right)$ of the polymers were determined by differential scanning calorimetry (DSC). TGA experiments were performed on a TGA Q5000IR (TA Instruments). Approximately 2-8 mg of extracted polymer sample was heated under nitrogen atmosphere at $10{ }^{\circ} \mathrm{C} \min ^{-1}$ to $900{ }^{\circ} \mathrm{C}$. $T_{\mathrm{d} 1}$ and $T_{\mathrm{d} 2}$ were taken at the initiation of sample degradation events. DSC experiments were performed on a DSC Q200 (TA Instruments). Between 2-4 mg of polymer sample were heated to $200{ }^{\circ} \mathrm{C}$ at $10{ }^{\circ} \mathrm{C} \min ^{-1}$, cooled to $-80{ }^{\circ} \mathrm{C}$ at $5{ }^{\circ} \mathrm{C} \mathrm{min}^{-1}$, and then heated back to $200{ }^{\circ} \mathrm{C}$ at $10{ }^{\circ} \mathrm{C} \mathrm{min}^{-1}$. The $T_{\mathrm{m}}$ and $T_{\mathrm{c}}$ were taken at the bottom or top of their peaks, respectively, if present. The $T_{\mathrm{g}}$ was taken in the middle of the transition. Analyses for DSC and TGA data were performed with TA Instruments Universal Analysis 2000 software.

\section{Infrared Spectroscopy}

Experiments were performed in a Bruker Tensor 27 FT-IR spectrometer equipped with an attenuated total reflection (ATR) stage. To confirm the presence of the azide functional group on copolymer samples, the stretching vibration at $\sim 2150 \mathrm{~cm}^{-1}$ was detected. ${ }^{15}$ Samples were scanned 16 times and the data analyzed in transmittance mode with the Bruker OPUS 6.5 software.

\section{References}

(1) Tappel, R. C.; Wang, Q.; Nomura, C. T. Precise Control of Repeating Unit Composition in Biodegradable poly(3-Hydroxyalkanoate) Polymers Synthesized by Escherichia Coli. J. Biosci. Bioeng. 2012, 113, 480486.

(2) Chong, J. M.; Heuft, M. A.; Rabbat, P. Solvent Effects on the Monobromination of $\alpha, \omega$-Diols: A Convenient Preparation of $\omega$-Bromoalkanols. J. Org. Chem. 2000, 65, 5837-5838.

(3) Becker, J.; Butt, L.; von Kiedrowski, V.; Mischler, E.; Quentin, F.; Hiersemann, M. Total Synthesis of (-)Ecklonialactone B. Org. Lett. 2013, 15, 5982-5985.

(4) Ardes-Guisot, N.; Alonzi, D. S.; Reinkensmeier, G.; Butters, T. D.; Norez, C.; Becq, F.; Shimada, Y.; Nakagawa, S.; Kato, A.; Blériot, Y.; Sollogoub, M.; Vauzeilles, B. Selection of the Biological Activity of DNJ Neoglycoconjugates through Click Length Variation of the Side Chain. Org. Biomol. Chem. 2011, 9, 5373-5388.

(5) Cao, B.; White, J. M.; Williams, S. J. Synthesis of Glycoconjugate Fragments of Mycobacterial Phosphatidylinositol Mannosides and Lipomannan. Beilstein J. Org. Chem. 2011, 7, 369-377.

(6) Schmidt, A.-K. C.; Stark, C. B. W. TPAP-Catalyzed Direct Oxidation of Primary Alcohols to Carboxylic Acids through Stabilized Aldehyde Hydrates. Org. Lett. 2011, 13, 4164-4167.

(7) Colombano, G.; Travelli, C.; Galli, U.; Caldarelli, A.; Chini, M. G.; Canonico, P. L.; Sorba, G.; Bifulco, G.; Tron, G. C.; Genazzani, A. A. A Novel Potent Nicotinamide Phosphoribosyltransferase Inhibitor Synthesized via Click Chemistry. J. Med. Chem. 2010, 53, 616-623. 
(8) Nagarajan, S. R.; Devadas, B.; Zupec, M. E.; Freeman, S. K.; Brown, D. L.; Lu, H. F.; Mehta, P. P.; Kishore, N. S.; McWherter, C. A.; Getman, D. P.; Gordon, J. I.; Sikorski, J. A. Conformationally Constrained [ $p$-( $\omega$-Aminoalkyl)phenacetyl]-L-Seryl-L-Lysyl Dipeptide Amides as Potent Peptidomimetic Inhibitors of Candida Albicans and Human Myristoyl-CoA:protein N-Myristoyl Transferase. J. Med. Chem. 1997, 40, 1422-1438.

(9) Shorey, B. J.; Lee, V.; Baldwin, J. E. Synthesis of the Arctic Sponge Alkaloid Viscosaline and the Marine Sponge Alkaloid Theonelladin C. Tetrahedron 2007, 63, 5587-5592.

(10) Johnstone, K. D.; Karoli, T.; Liu, L.; Dredge, K.; Copeman, E.; Li, C. P.; Davis, K.; Hammond, E.; Bytheway, I.; Kostewicz, E.; Chiu, F. C. K.; Shackleford, D. M.; Charman, S. A.; Charman, W. N.; Harenberg, J.; Gonda, T. J.; Ferro, V. Synthesis and Biological Evaluation of Polysulfated Oligosaccharide Glycosides as Inhibitors of Angiogenesis and Tumor Growth. J. Med. Chem. 2010, 53, 1686-1699.

(11) Murozuka, Y.; Kasuya, M. C. Z.; Kobayashi, M.; Watanabe, Y.; Sato, T.; Hatanaka, K. Efficient Sialylation on Azidododecyl Lactosides by Using B16 Melanoma Cells. Chem. Biodivers. 2005, 2, 10631078.

(12) Hang, H. C.; Geutjes, E.-J.; Grotenbreg, G.; Pollington, A. M.; Bijlmakers, M. J.; Ploegh, H. L. Chemical Probes for the Rapid Detection of Fatty-Acylated Proteins in Mammalian Cells. J. Am. Chem. Soc. 2007, 129, 2744-2745.

(13) Sambrook, J.; Russell, D. W. Molecular Cloning: A Laboratory Manual, Volume 1; CSHL Press, 2001.

(14) Tappel, R. C.; Kucharski, J. M.; Mastroianni, J. M.; Stipanovic, A. J.; Nomura, C. T. Biosynthesis of poly[$(R)-3$-Hydroxyalkanoate] Copolymers with Controlled Repeating Unit Compositions and Physical Properties. Biomacromolecules 2012, 13, 2964-2972.

(15) Lieber, E.; Rao, C. N. R.; Chao, T. S.; Hoffman, C. W. W. Infrared Spectra of Organic Azides. Anal. Chem. 1957, 29, 916-918. 
NMR Spectra

\section{Synthetic Intermediates}

8-Bromo-1-octanol (2)

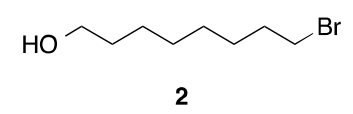

2

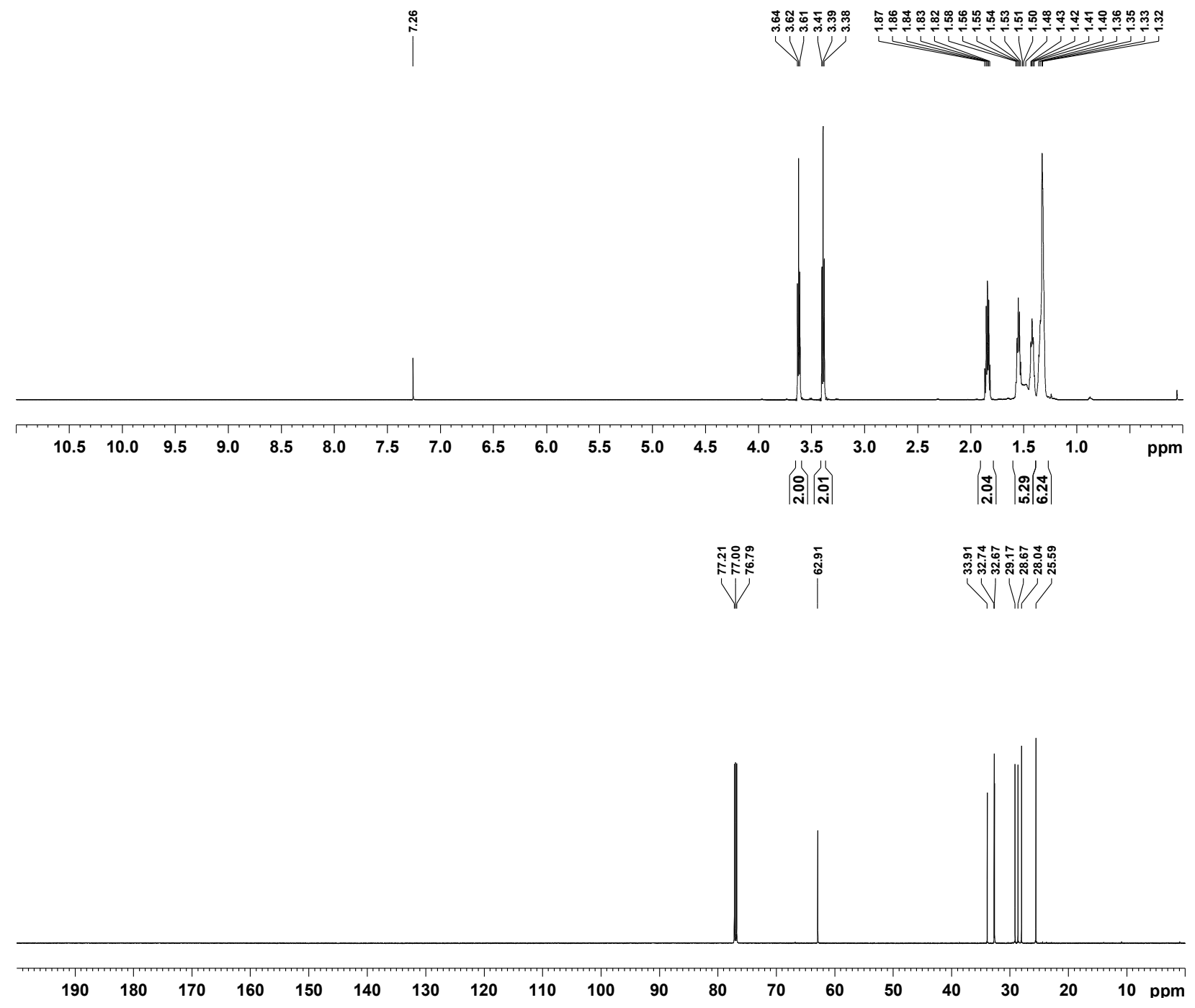


8-Azido-1-octanol (3)

$\mathrm{HO}_{3} \mathrm{~N}_{3}$
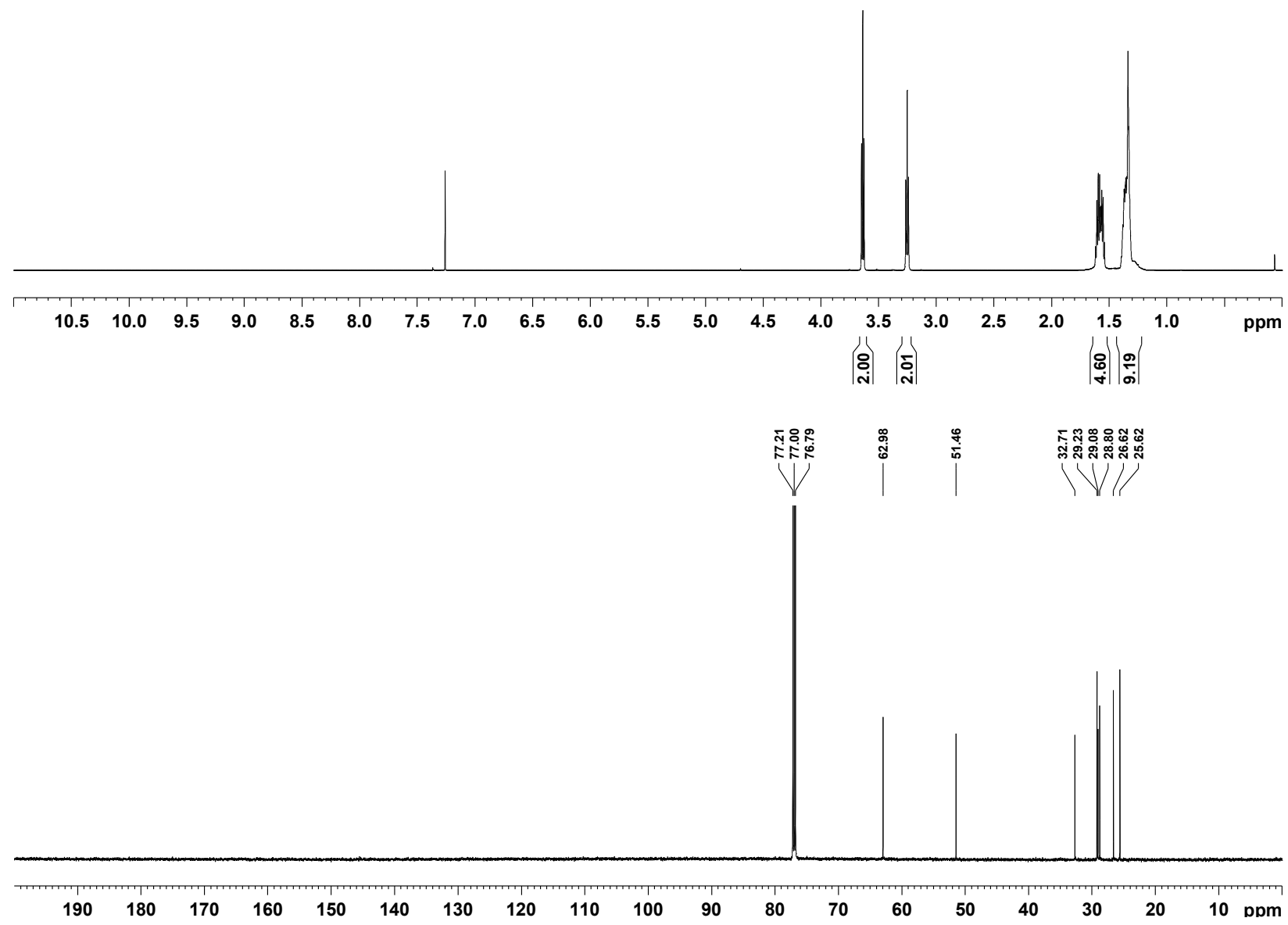
8-Azidooctanoic acid (4)

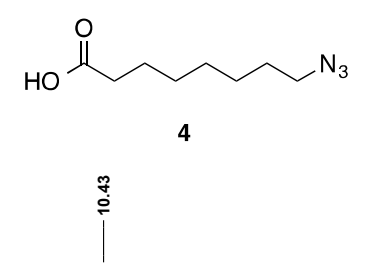

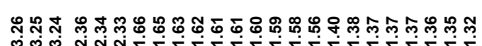
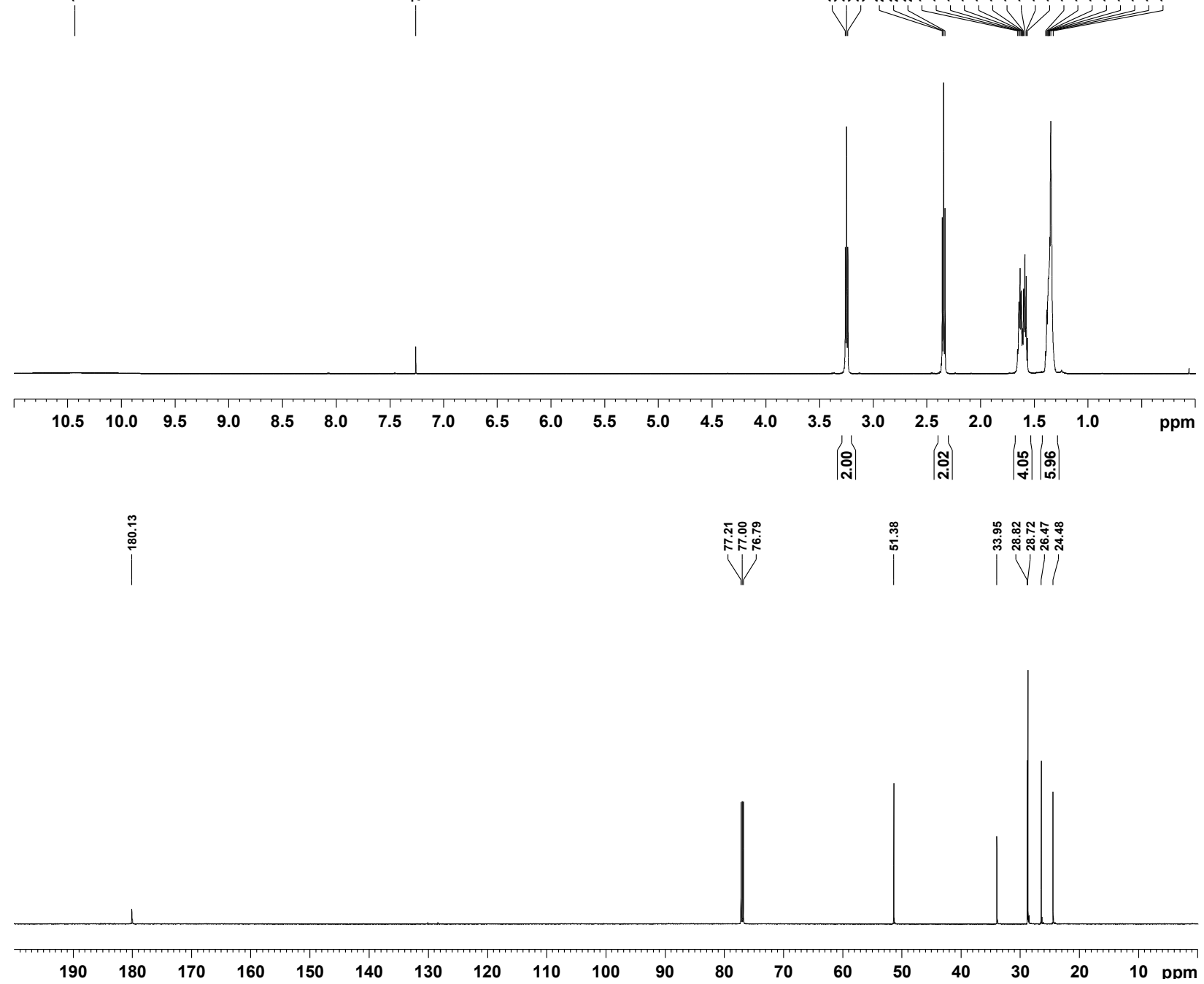
10-Azidodecanoic acid (6)<smiles>N#CCCCCCCCCCC(=O)O</smiles>

6
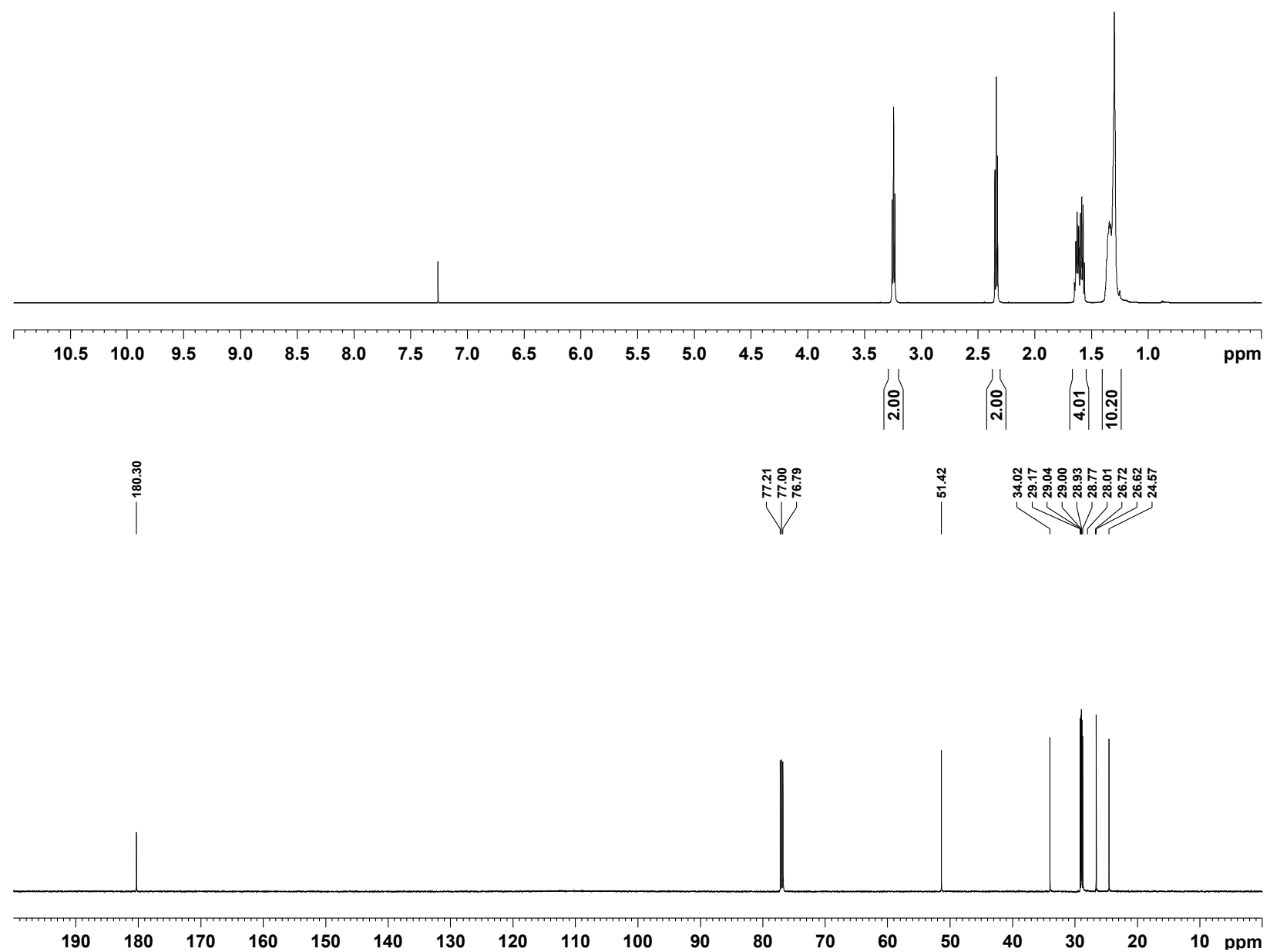
12-Bromo-1-dodecanol (8)

$\mathrm{HO}^{\mathrm{Br}}$

8

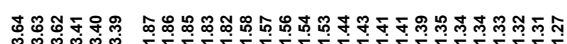
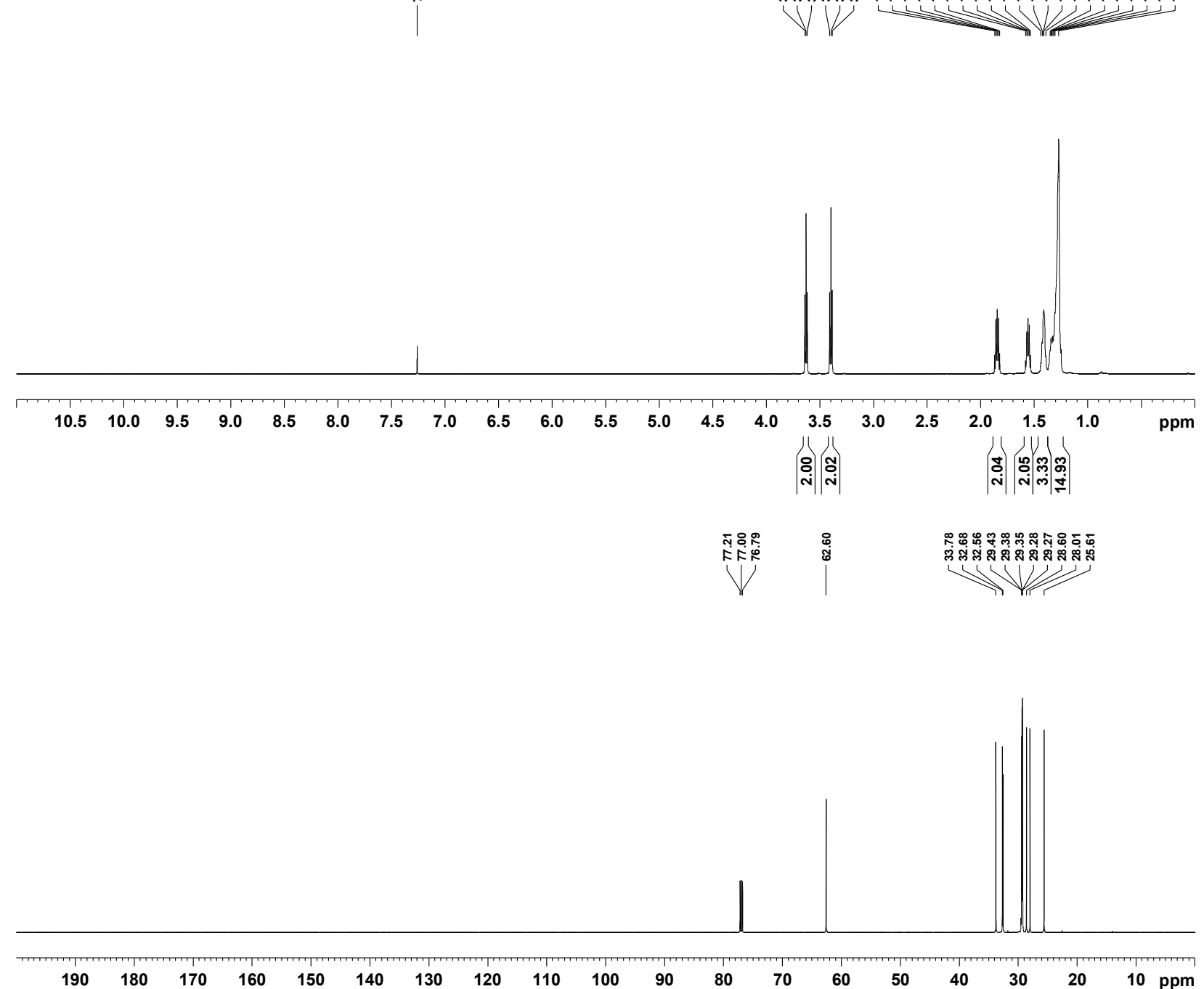
12-Azido-1-dodecanol (9)<smiles>NCCCCCCCCCCCCCO</smiles>

9

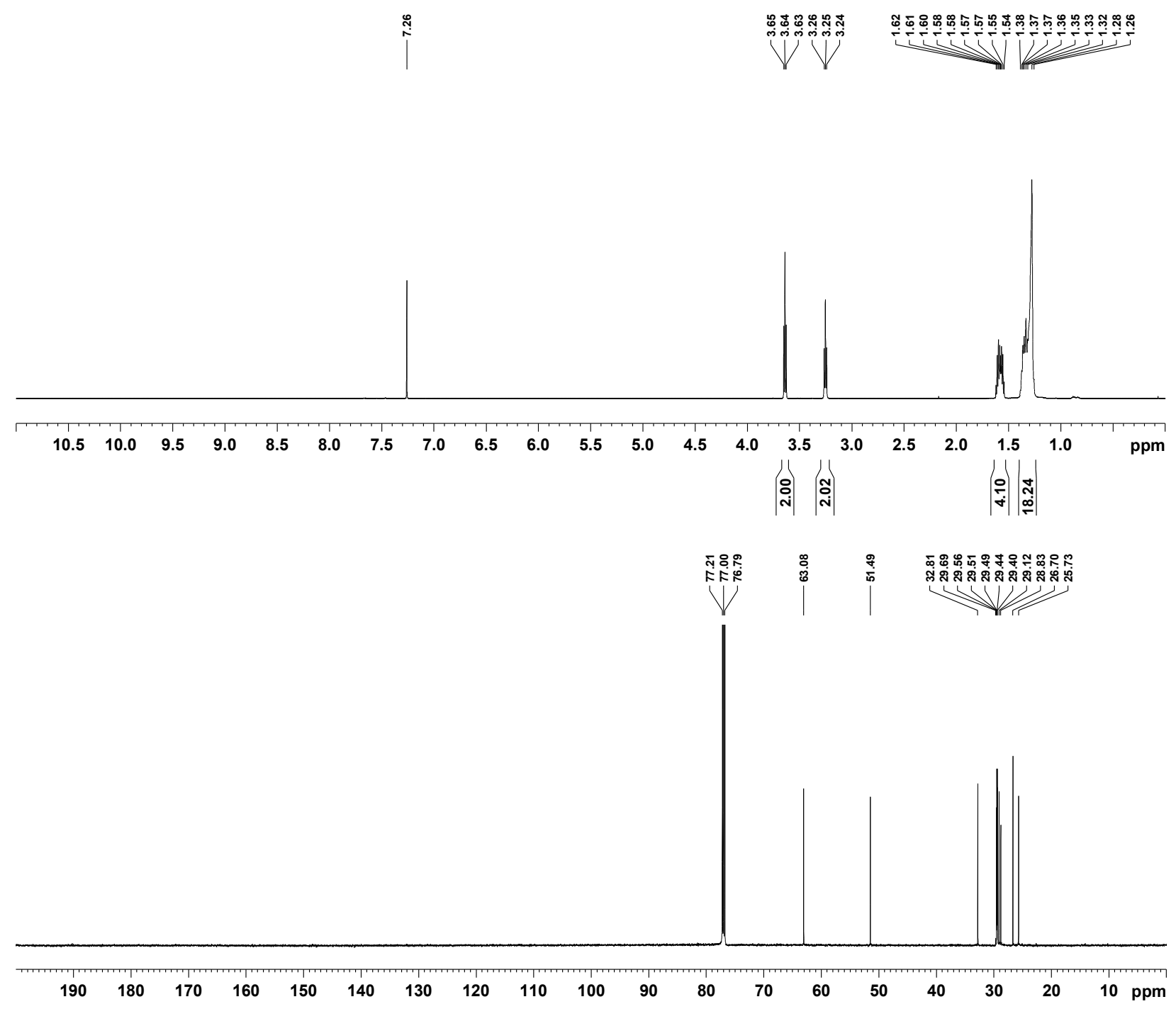


12-Azidododecanoic acid (10)<smiles>N#CCCCCCCCCCCCC(=O)O</smiles>

10
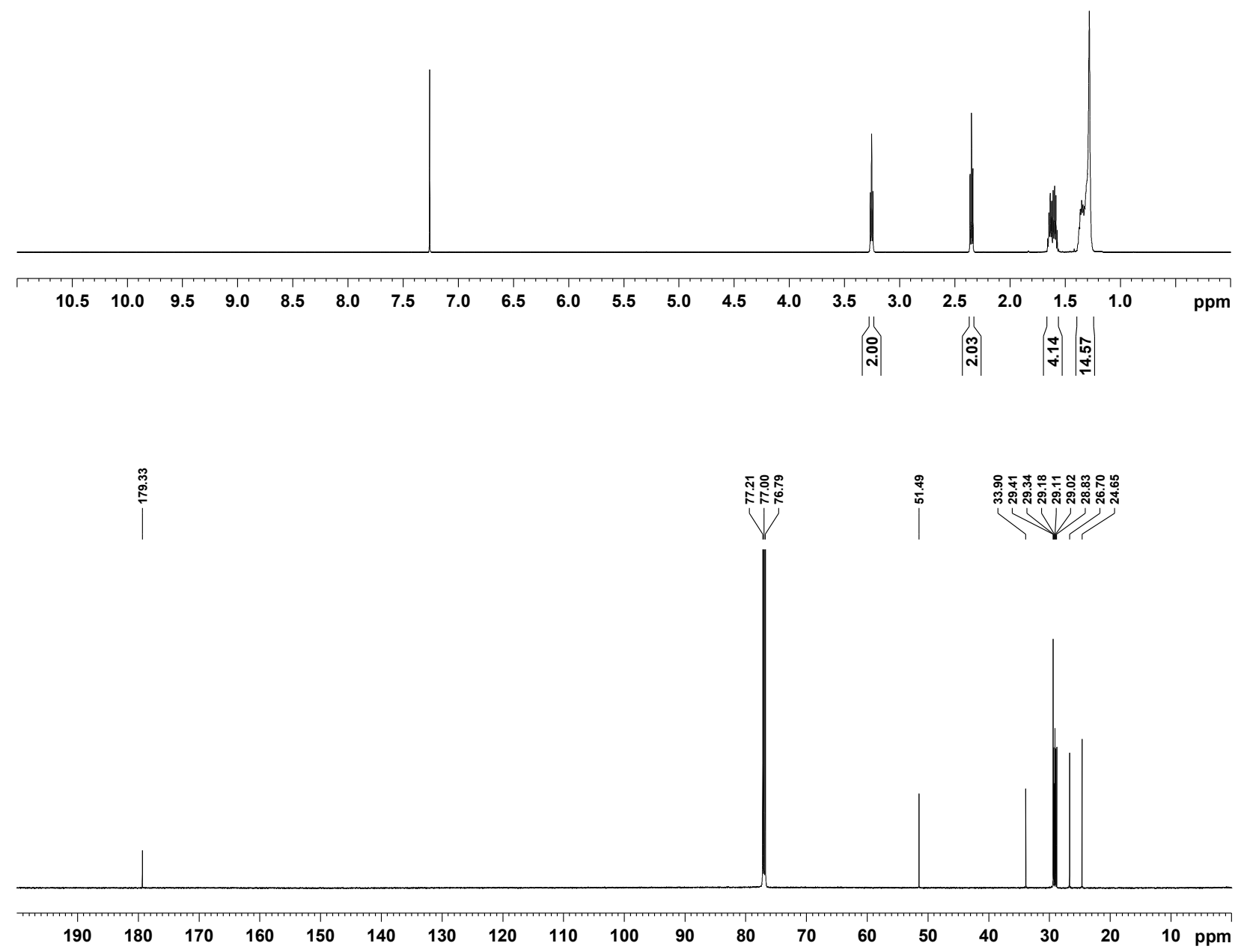
Assignment and Structural Confirmation of $\mathrm{PHODN}_{3}-\mathrm{BCN}-\mathrm{OH}$

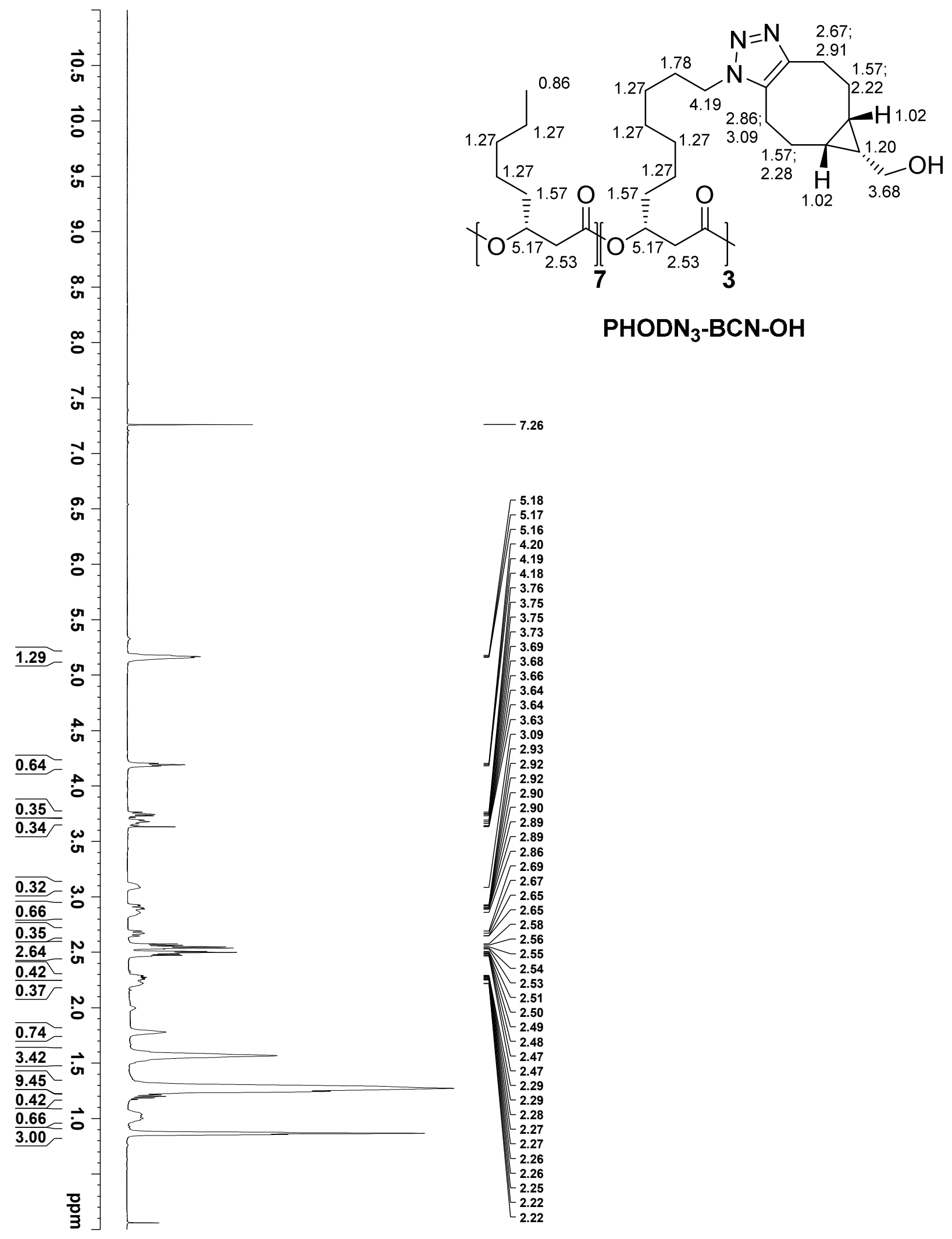




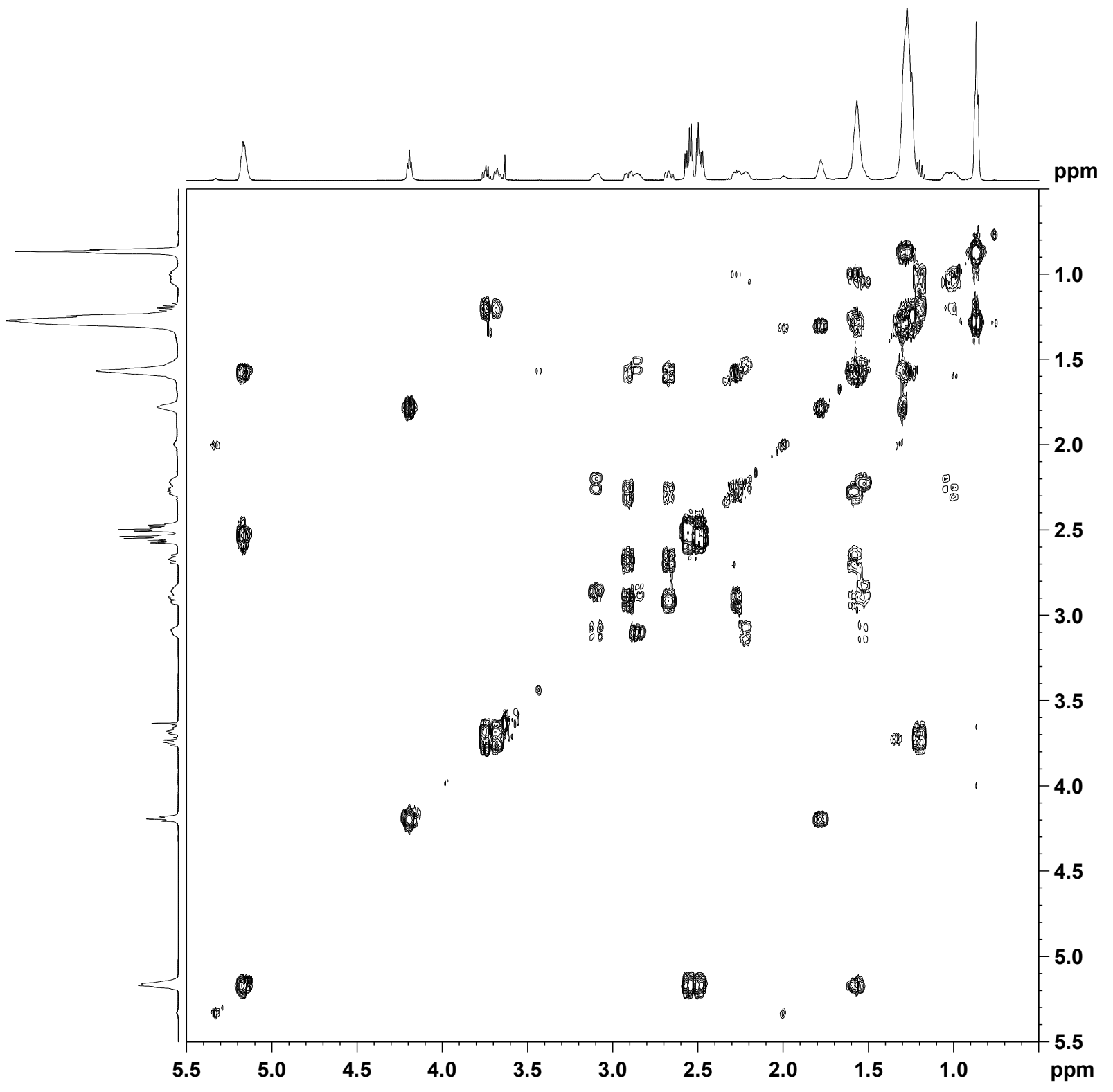


HSQC with adiabatic bilevel decoupling

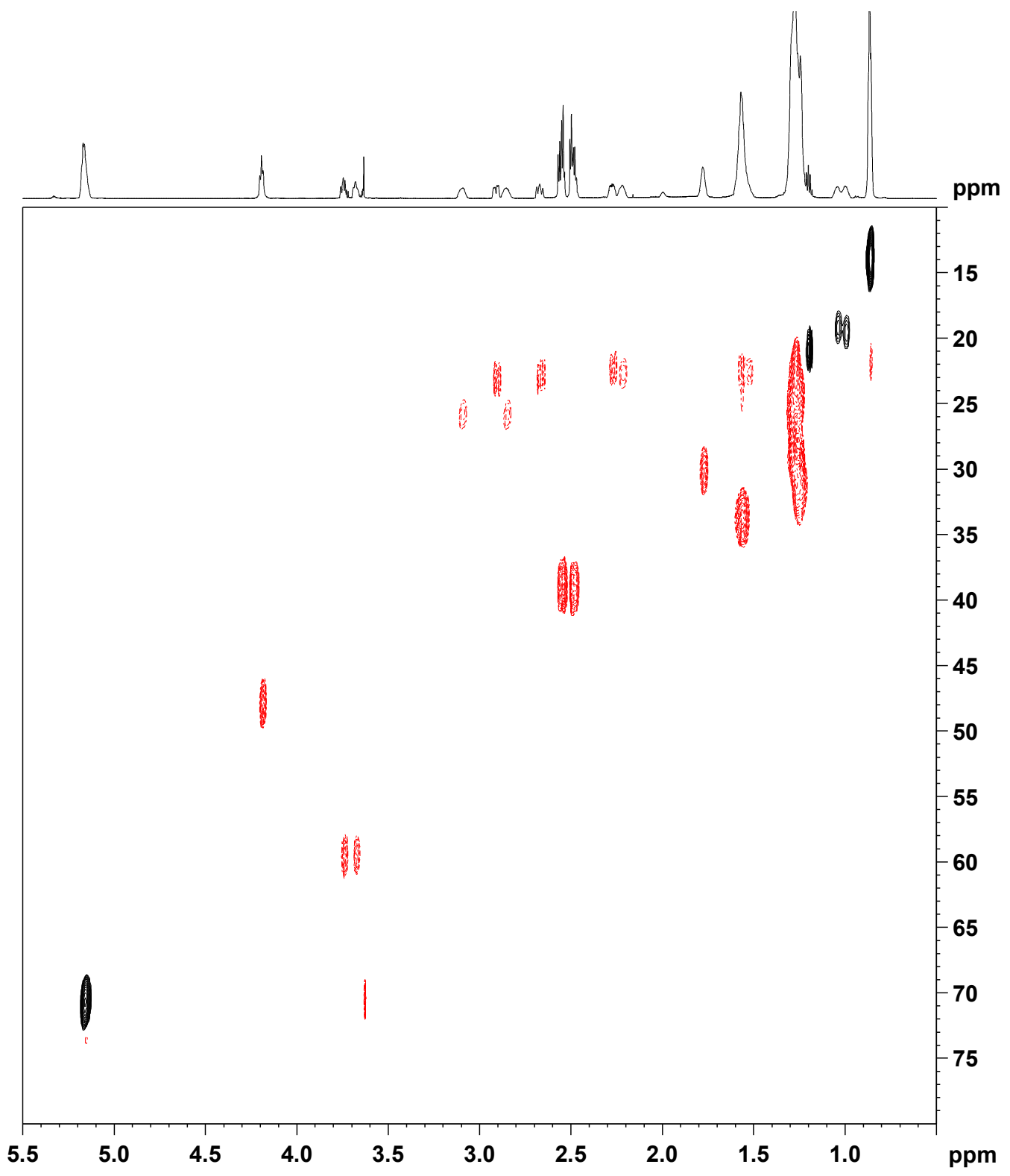


1D TOCSY Irradiated from $=3.78-3.63 \mathrm{ppm}$

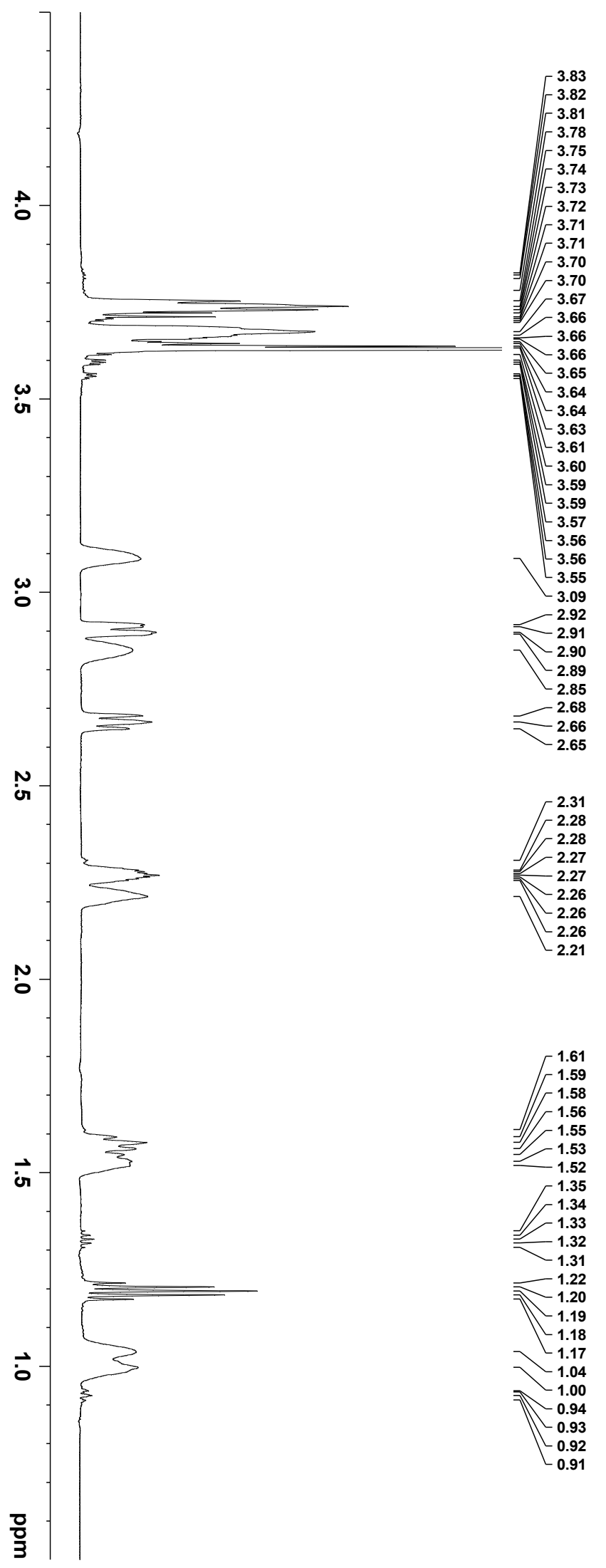


Spectra of Azido-PHA Homopolymers
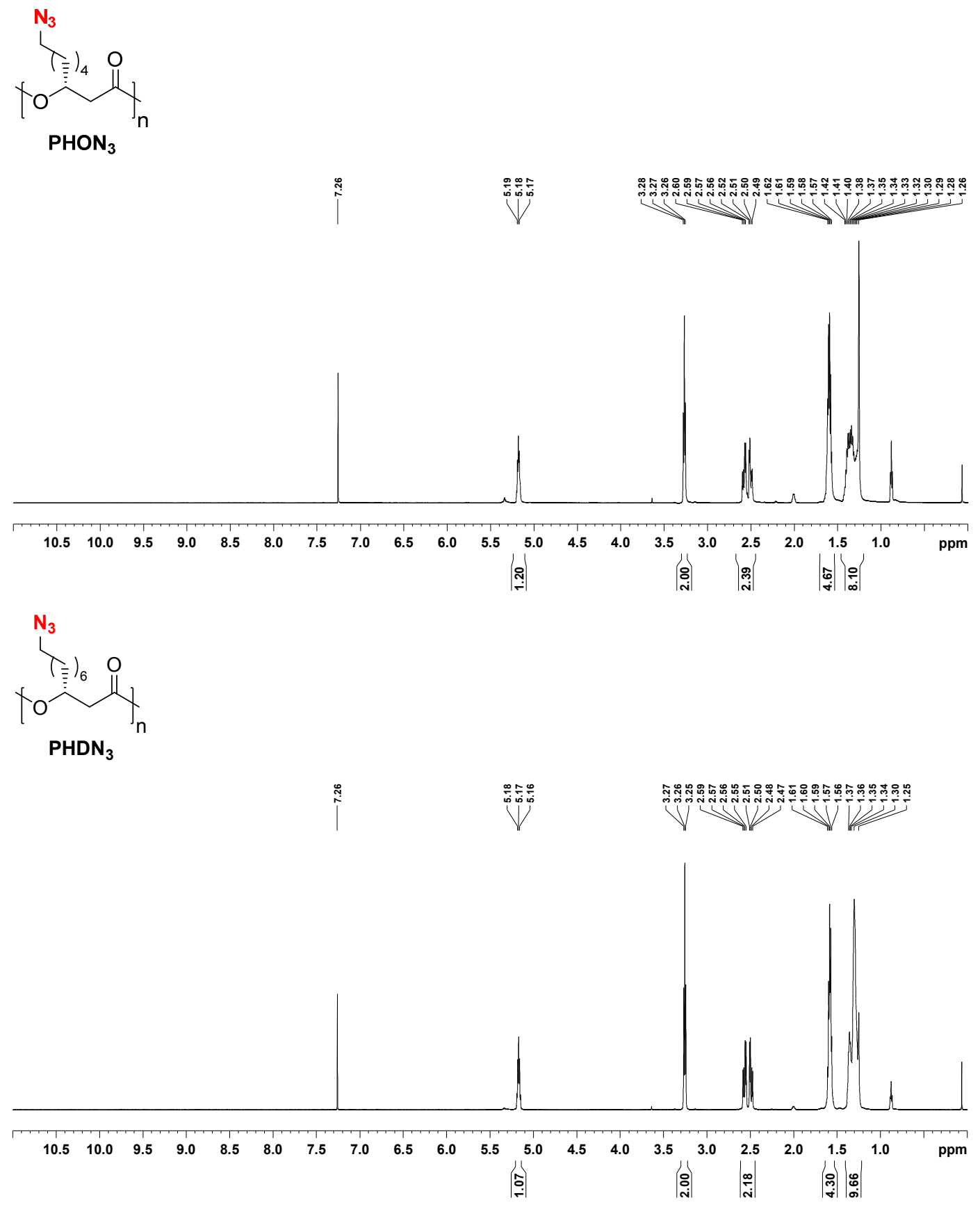
$\mathrm{N}_{3}$<smiles>CCCC(C)OC(C)CC(C)=O</smiles>

PHDDN $_{3}$

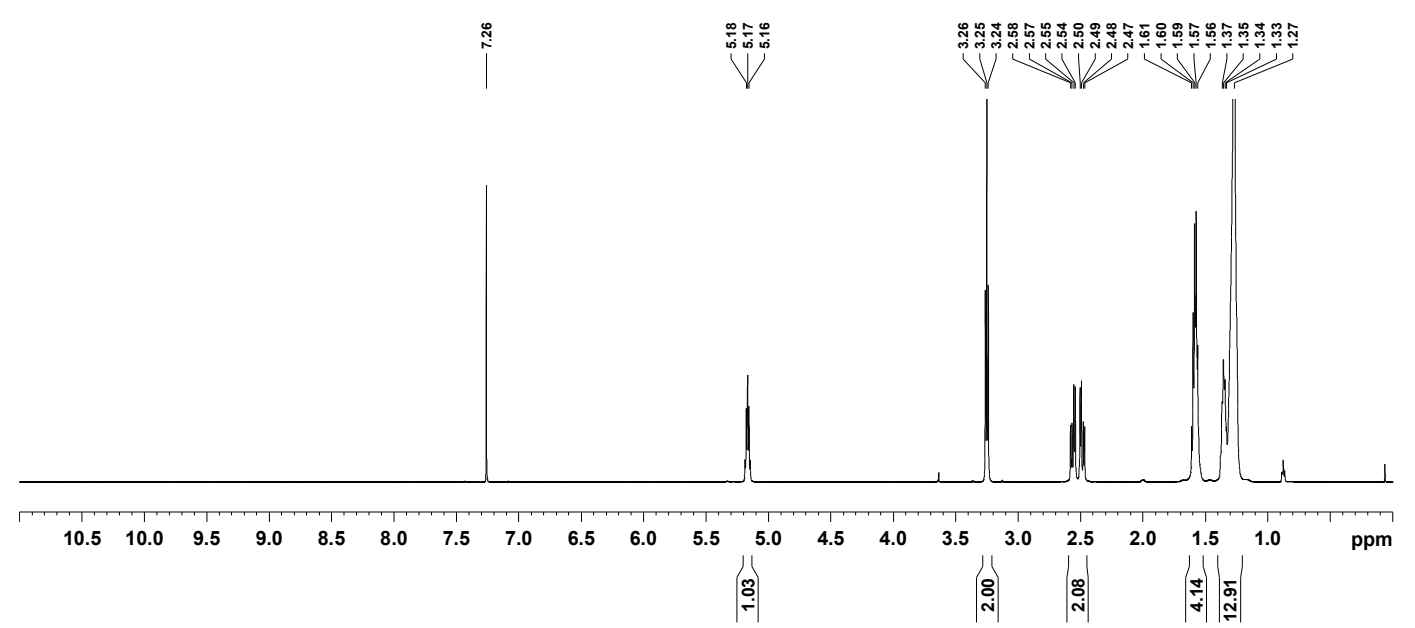


Sample Spectra for the Construction of Calibration Curves

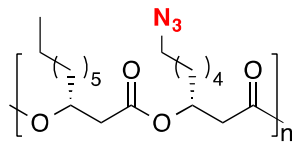

$\mathrm{PHOON}_{3}$

$\left(1: 0.020 \mathrm{C} 8: \mathrm{C} \mathrm{N}_{3}\right)$

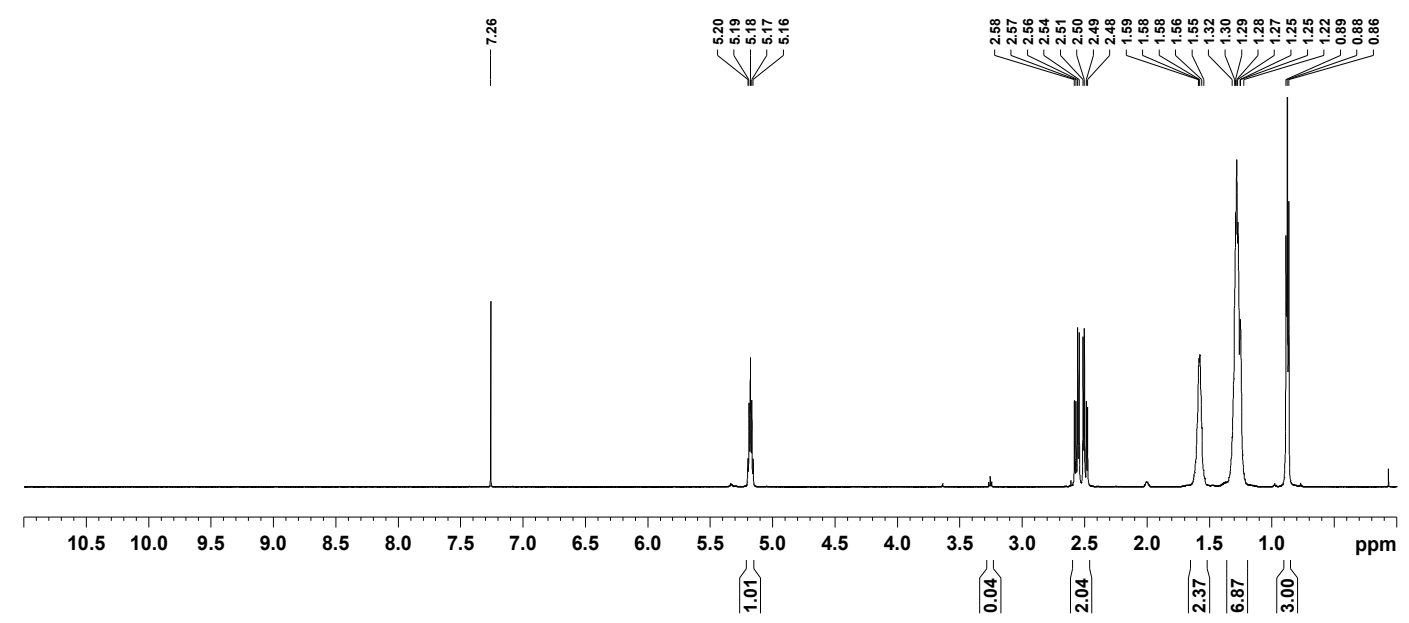

\section{$\left(1: 0.055 \mathrm{C} 8: \mathrm{C} \mathrm{N}_{3}\right)$}

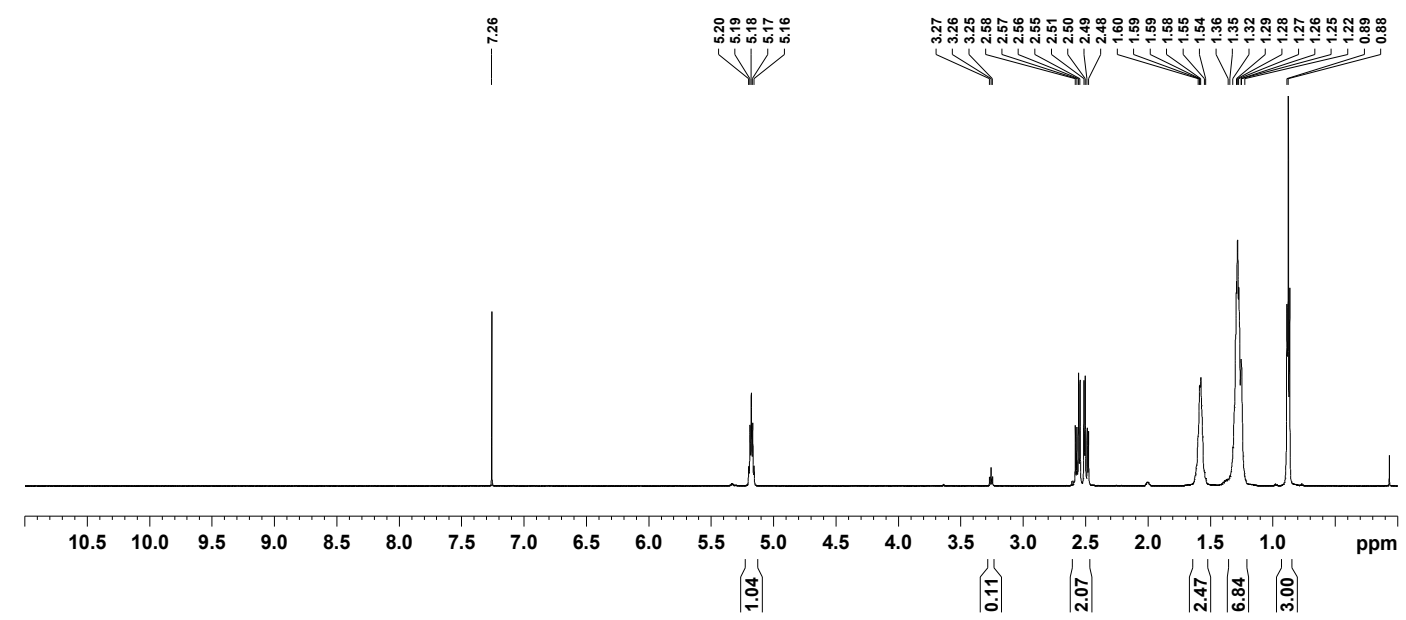

\section{$\left(1: 0.140 \mathrm{C8}: \mathrm{C8N}_{3}\right)$}

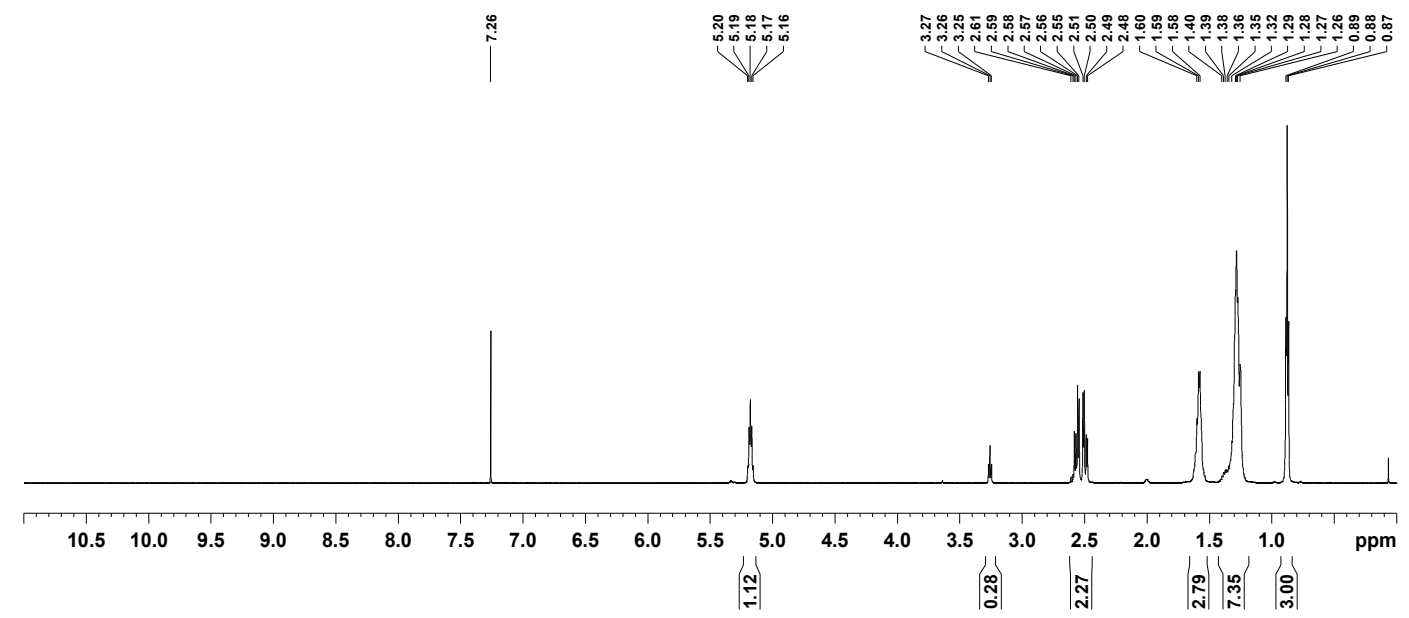


(1 : $0.290 \mathrm{C8}: \mathrm{C8N}_{3}$ )
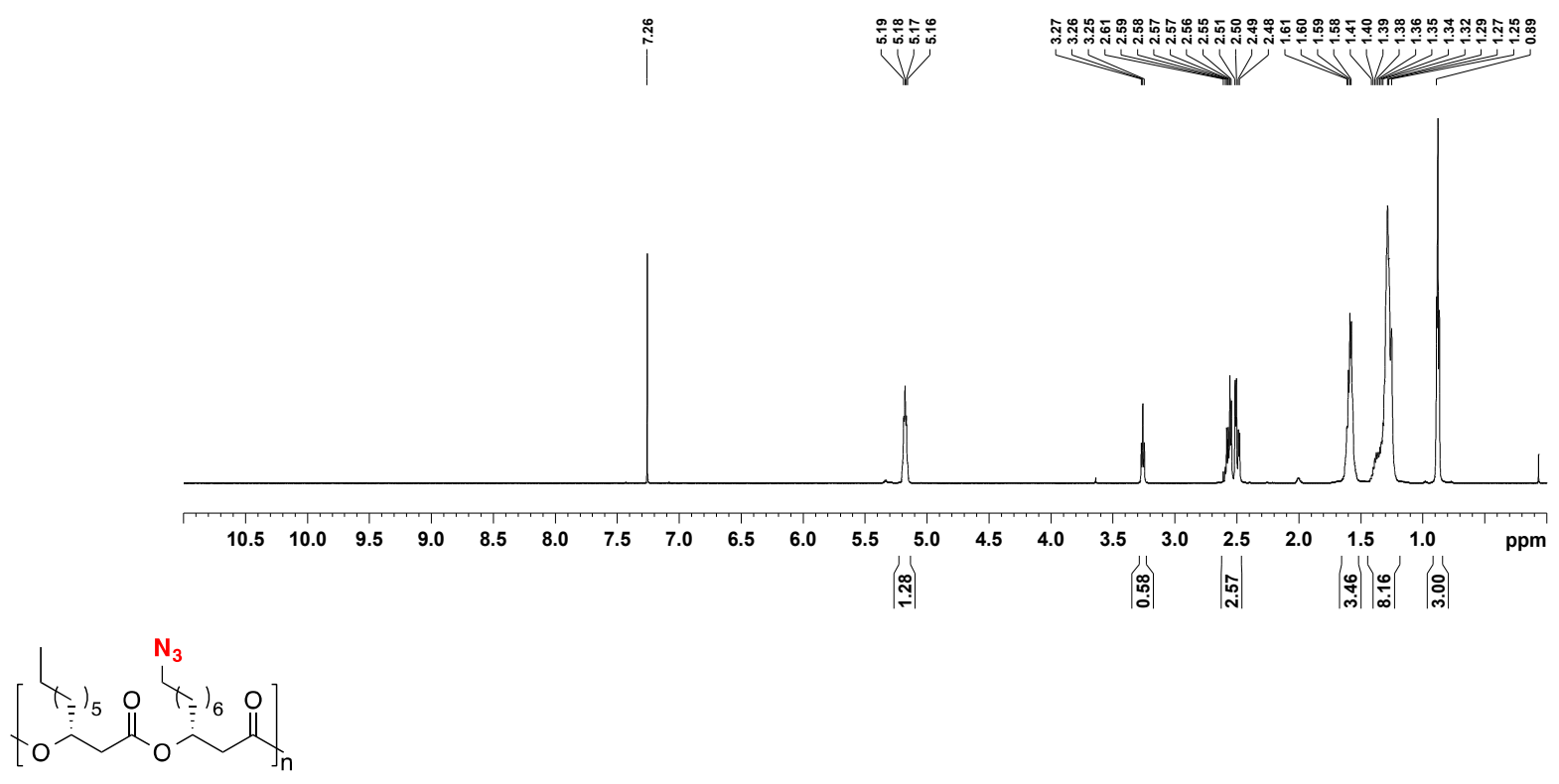

$\mathrm{PHODN}_{3}$

$\left(1: 0.045 \mathrm{C} 8: \mathrm{C10N}_{3}\right)$

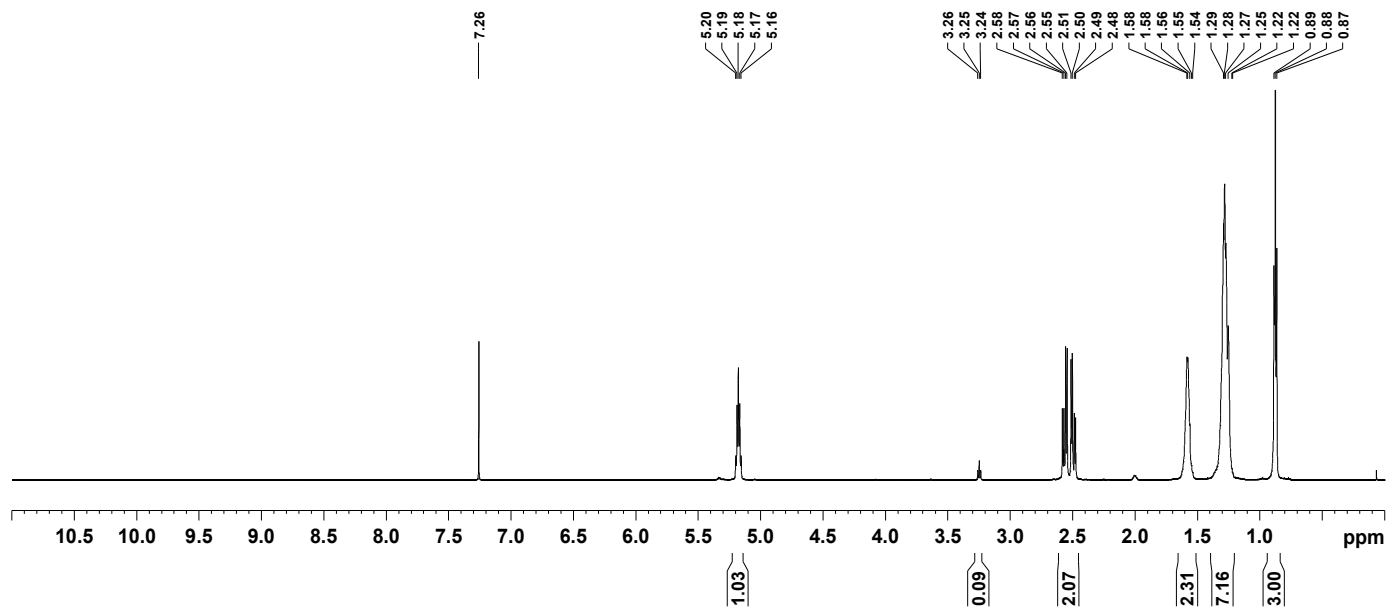

\section{$\left(1: 0.115 \mathrm{C} 8: \mathrm{C10N}_{3}\right)$}

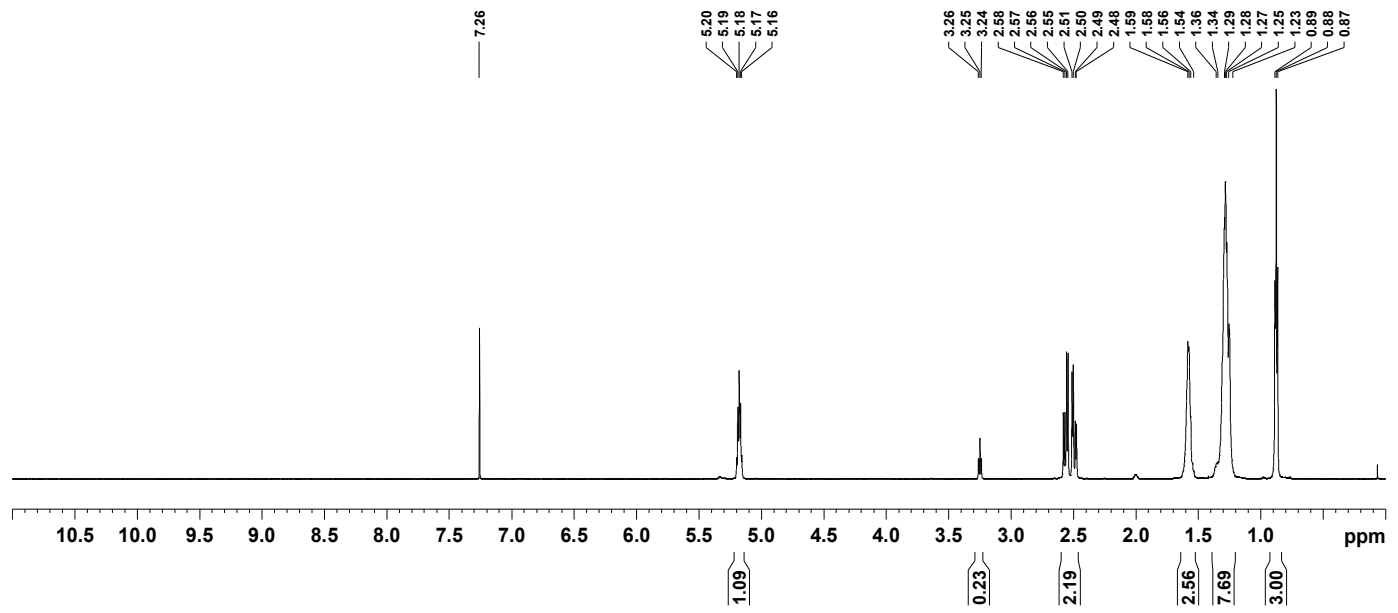




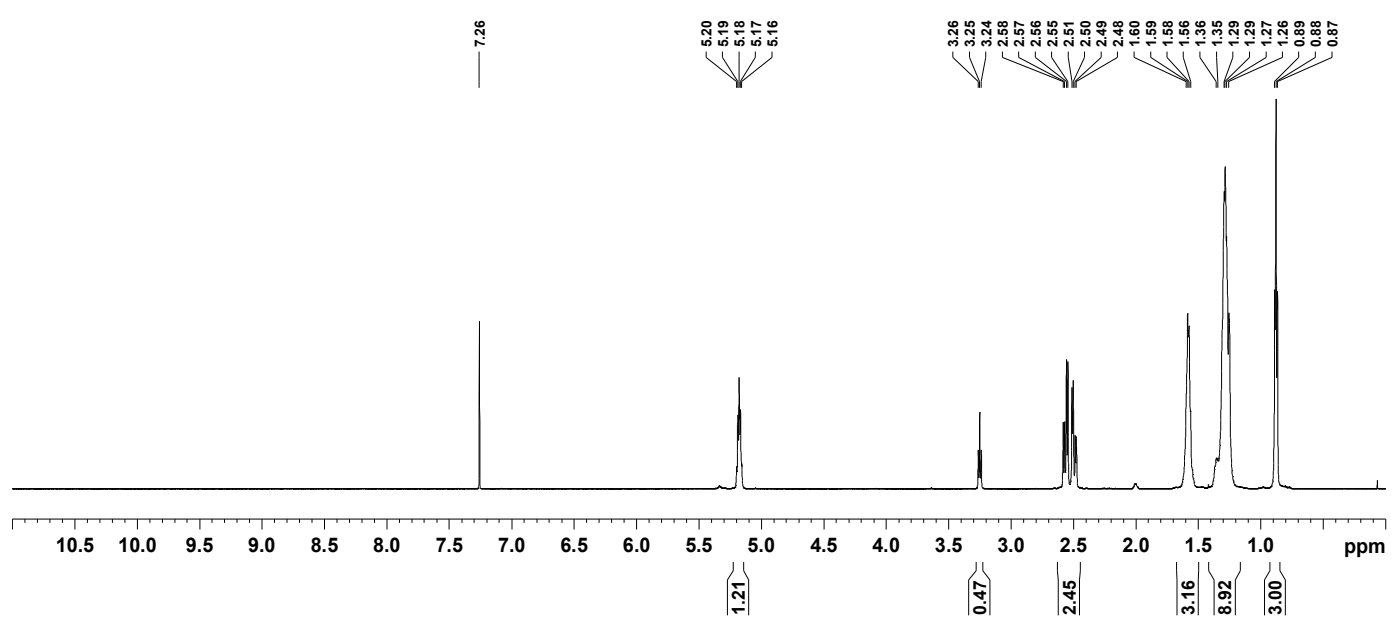

\section{$\left(1: 0.465 \mathrm{C} 8: \mathrm{C10N}_{3}\right)$}
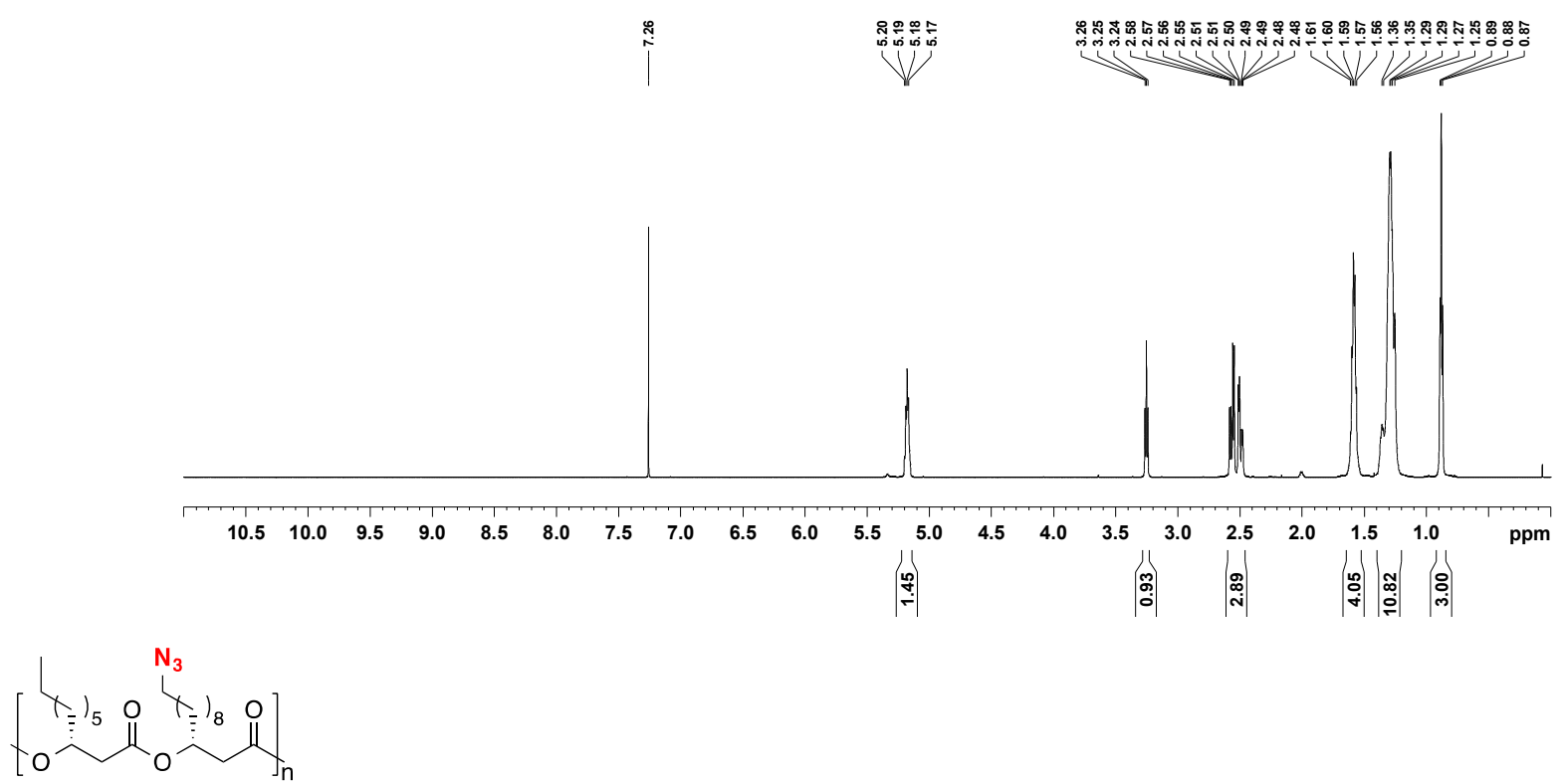

PHODDN $_{3}$

(1: $\left.0.070 \mathrm{C} 8: \mathrm{C1}_{12} \mathrm{~N}_{3}\right)$

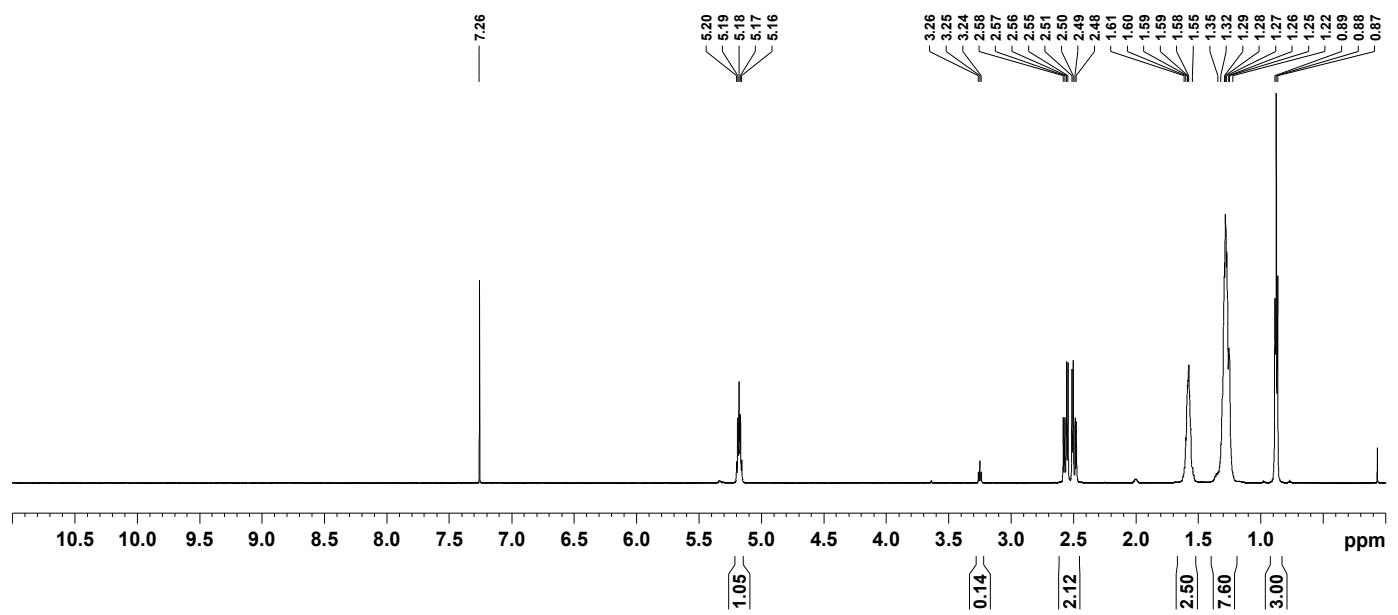


(1 : $0.245 \mathrm{C8}: \mathrm{C12N}_{3}$ )

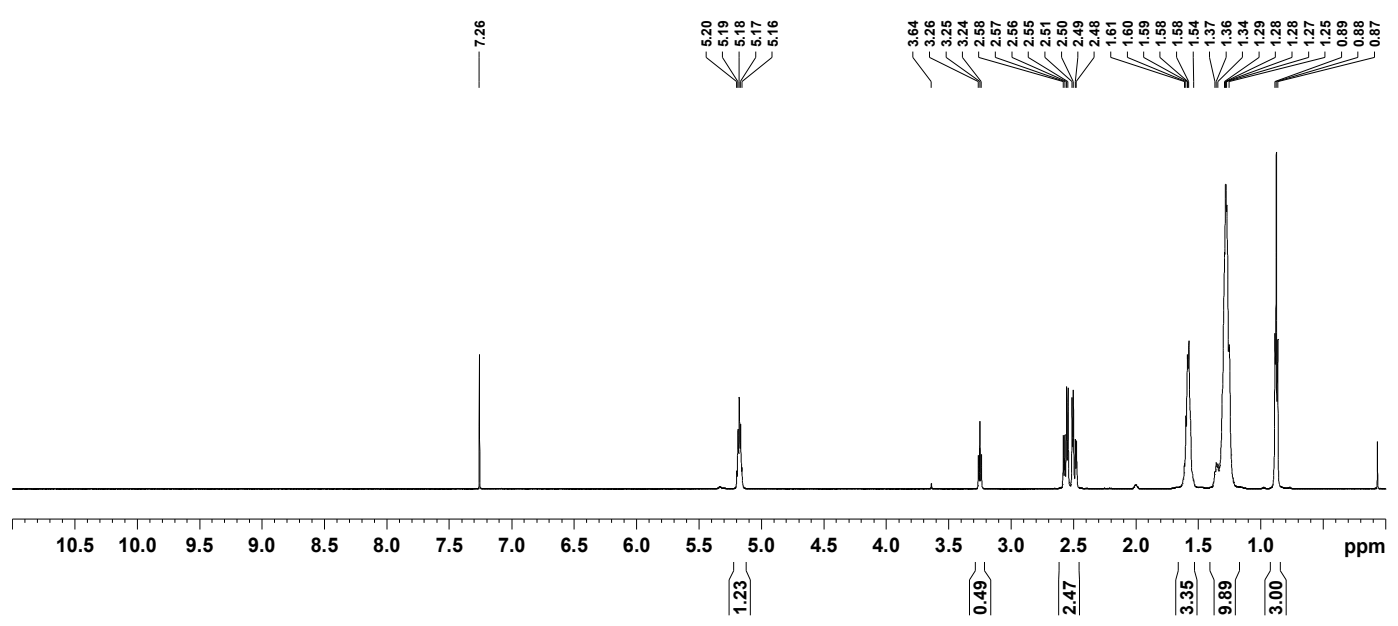

\section{$\left(1: 0.520 \mathrm{C} 8: \mathrm{C12N}_{3}\right)$}

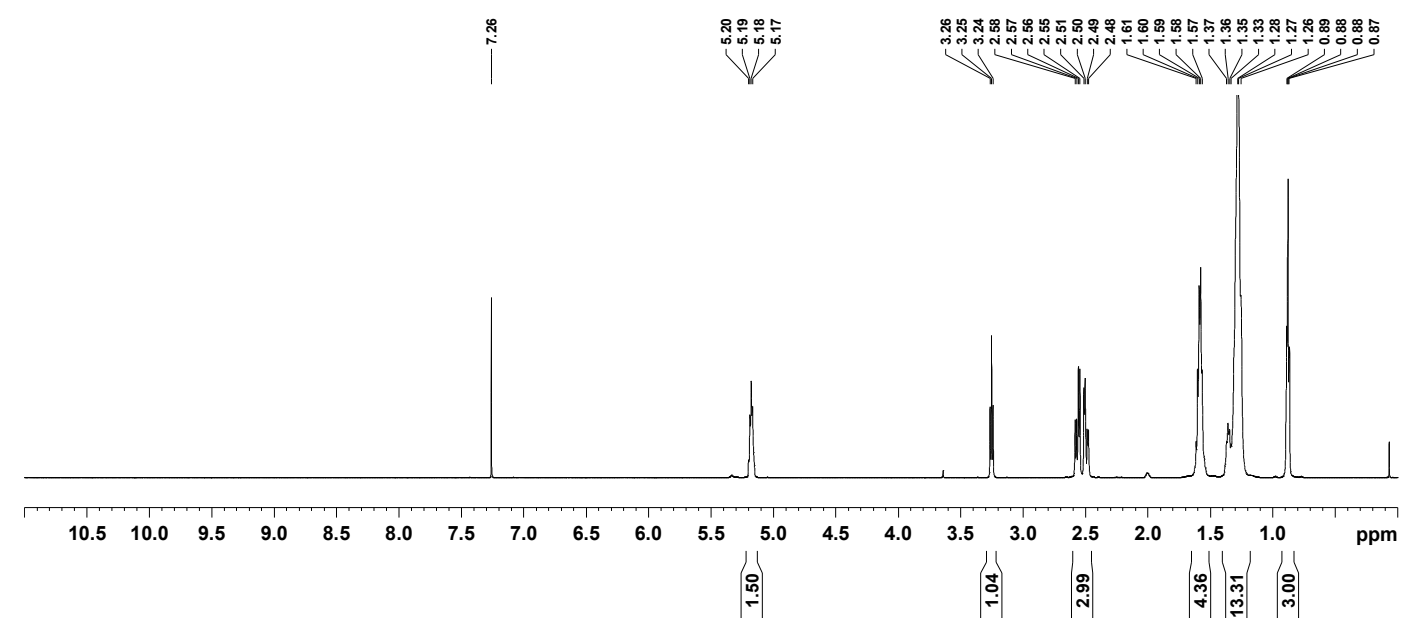

\section{$\left(1: 1.960 \mathrm{C} 8: \mathrm{C}^{2} \mathrm{~N}_{3}\right)$}

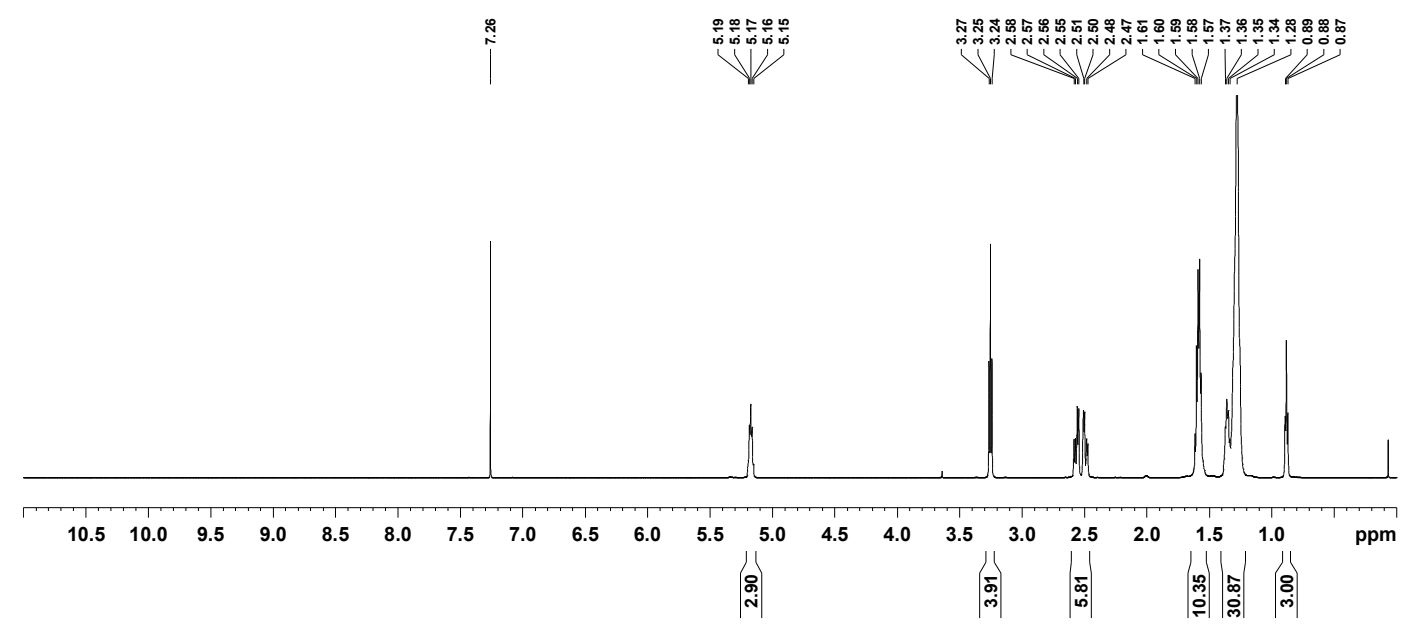




\section{Calibration Curves}

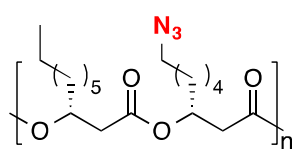

$\mathrm{PHOON}_{3}$

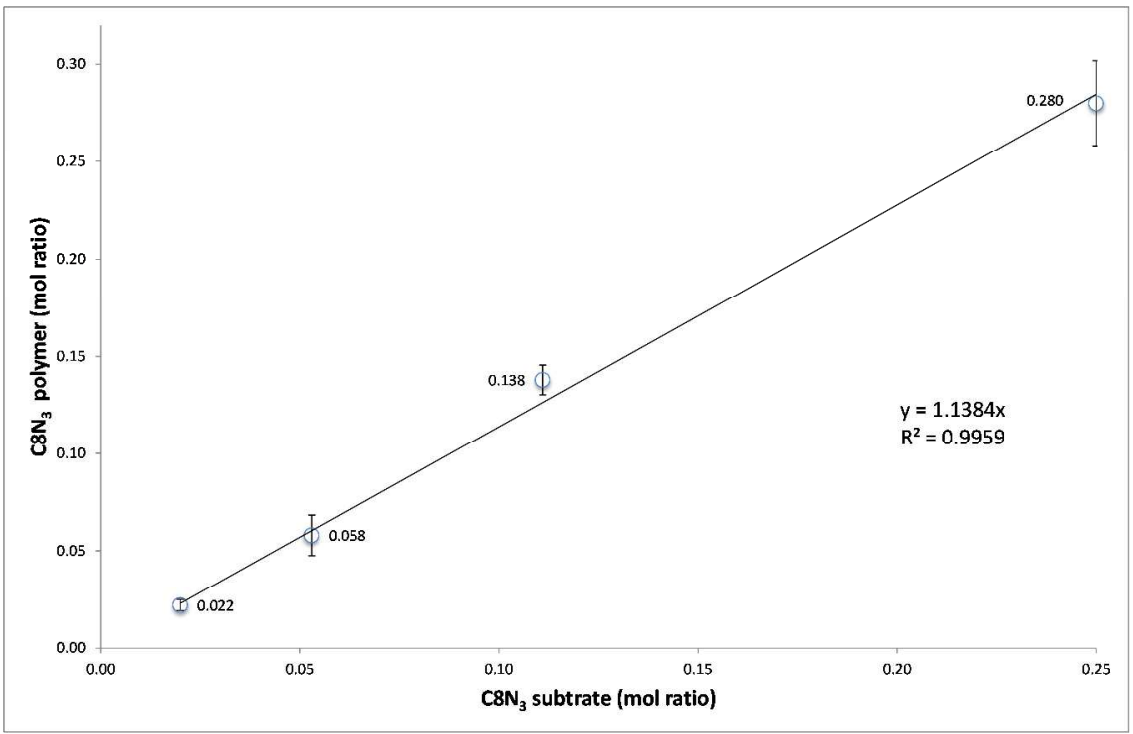

$L_{0}^{L_{0}}$

$\mathrm{PHODN}_{3}$

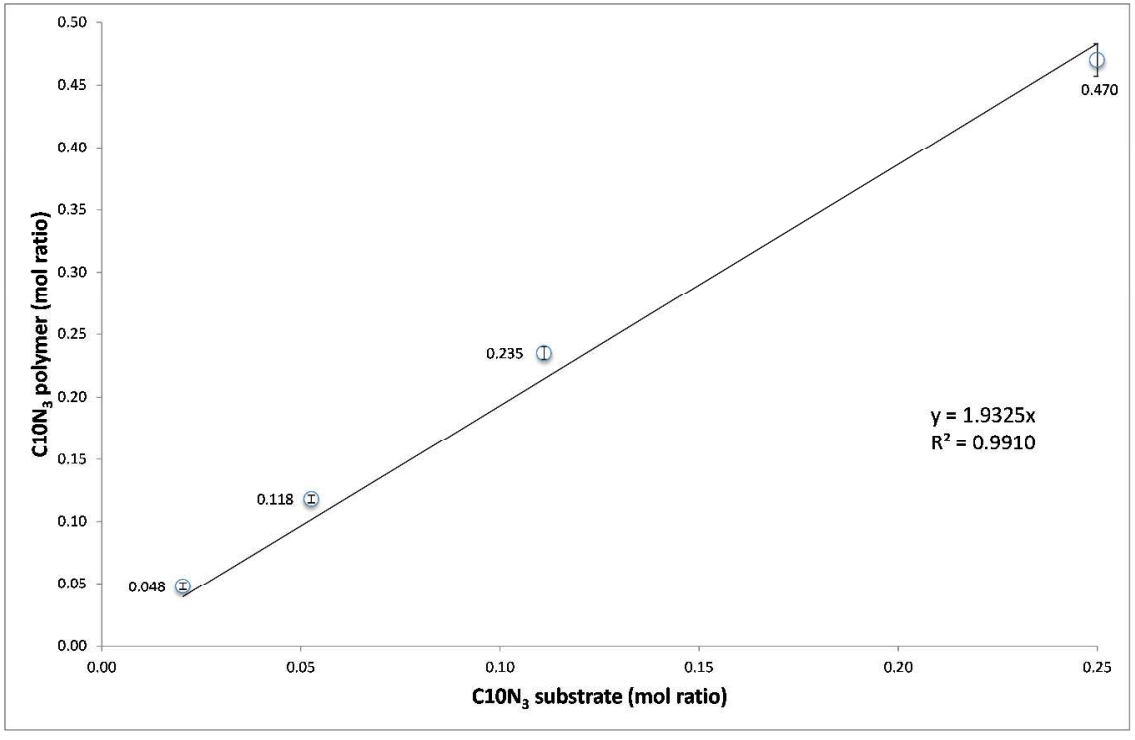

\begin{tabular}{cc}
\hline $\begin{array}{c}\text { Substrate } \\
\text { mol ratio } \\
\left(\mathbf{C 8 N}_{3}: \mathbf{C 8}\right)\end{array}$ & $\begin{array}{c}\text { Polymer } \\
\text { mol ratio } \\
\left(\mathbf{C 8 N}_{3}: \mathbf{C 8}\right)\end{array}$ \\
\hline 0.020 & $0.022 \pm 0.003$ \\
0.053 & $0.058 \pm 0.010$ \\
0.111 & $0.138 \pm 0.008$ \\
0.250 & $0.280 \pm 0.022$
\end{tabular}

\begin{tabular}{cc}
\hline $\begin{array}{c}\text { Substrate } \\
\text { mol ratio } \\
\left(\mathbf{C 1 0 N}_{3}: \mathbf{C 8}\right)\end{array}$ & $\begin{array}{c}\text { Polymer } \\
\text { mol ratio } \\
\left(\mathbf{C} 10 N_{3}: \mathbf{C 8}\right)\end{array}$ \\
\hline 0.020 & $0.048 \pm 0.003$ \\
0.053 & $0.118 \pm 0.003$ \\
0.111 & $0.235 \pm 0.005$ \\
0.250 & $0.470 \pm 0.013$
\end{tabular}



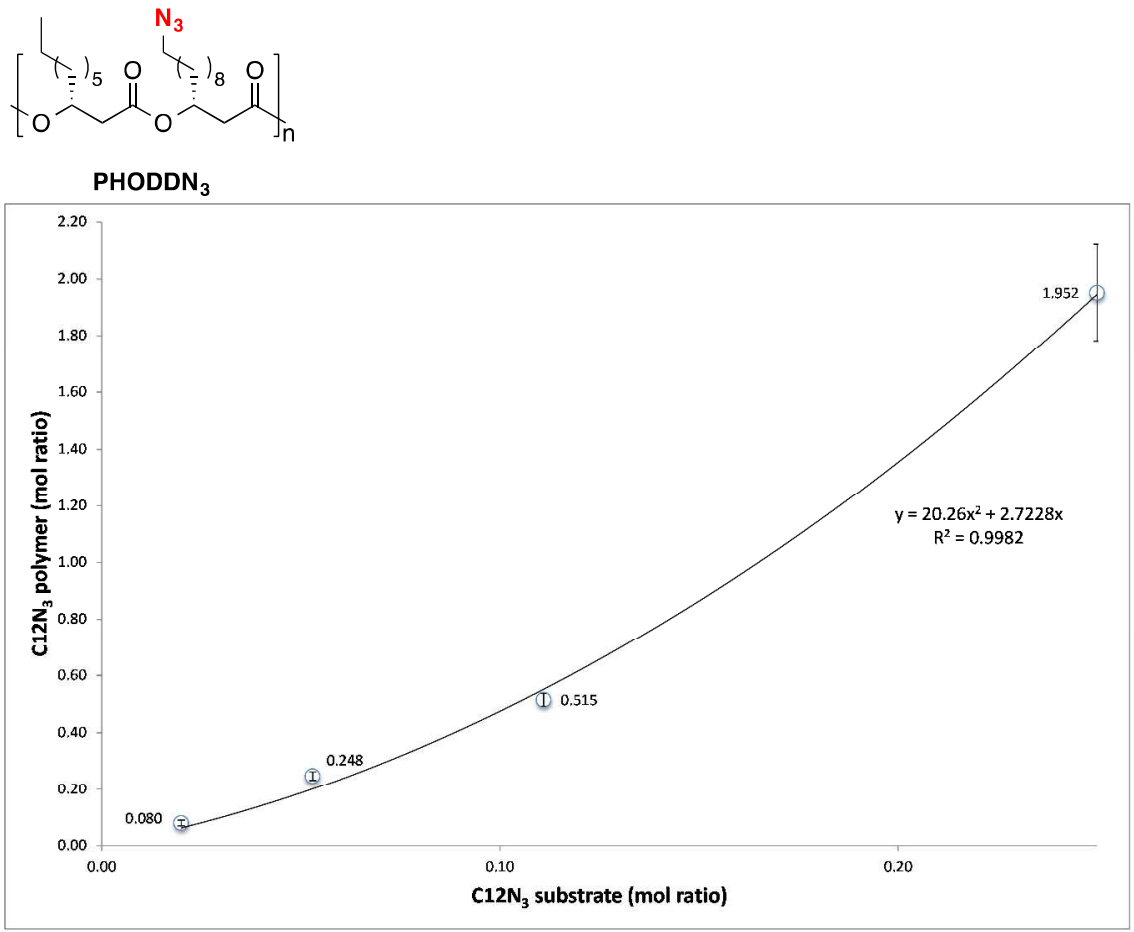

\begin{tabular}{cc}
\hline $\begin{array}{c}\text { Substrate } \\
\text { mol ratio } \\
(\mathbf{C 1 2 N}: \mathbf{C 8})\end{array}$ & $\begin{array}{c}\text { Polymer } \\
\text { mol ratio } \\
\left(\mathbf{C 1 2 N}_{3}: \mathbf{C 8}\right)\end{array}$ \\
\hline 0.020 & $0.080 \pm 0.010$ \\
0.053 & $0.248 \pm 0.015$ \\
0.111 & $0.515 \pm 0.023$ \\
0.250 & $1.952 \pm 0.170$
\end{tabular}




\section{Isolated Polymer Yields}

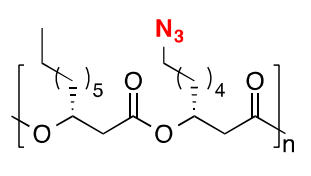

$\mathrm{PHOON}_{3}$

\begin{tabular}{|c|c|c|c|c|}
\hline $\begin{array}{l}\text { Substrate mol ratio } \\
\qquad\left(\mathrm{C} 8: \mathrm{C10N}_{3}\right)\end{array}$ & $\begin{array}{c}\text { CDW } \\
\left(g^{-1}\right)\end{array}$ & $\begin{array}{l}\text { PHA yield }^{a} \\
\text { (mass \%) }\end{array}$ & $\begin{array}{c}\text { PHA/CDW ratio } \\
\text { (mass \%) }\end{array}$ & $\begin{array}{l}\text { Polymer mol ratio } \\
\qquad\left(\mathrm{C} 8: \mathrm{C}^{2} \mathrm{~N}_{3}\right)\end{array}$ \\
\hline $1: 0.020$ & $1.25 \pm 0.21$ & $23.3 \pm 6.1$ & $28.2 \pm 11.1$ & $1: 0.022 \pm 0.003$ \\
\hline $1: 0.053$ & $1.07 \pm 0.09$ & $20.2 \pm 0.5$ & $27.7 \pm 1.6$ & $1: 0.058 \pm 0.010$ \\
\hline $1: 0.111$ & $1.23 \pm 0.09$ & $21.6 \pm 0.2$ & $26.3 \pm 1.6$ & $1: 0.138 \pm 0.008$ \\
\hline $1: 0.250$ & $1.18 \pm 0.08$ & $19.3 \pm 0.2$ & $25.1 \pm 2.0$ & $1: 0.280 \pm 0.022$ \\
\hline
\end{tabular}

${ }^{\mathrm{a}} \mathrm{Based}$ on theoretical conversion of fatty acids to polymer. ${ }^{\mathrm{b}}$ Ratio of polymer produced and CDW.

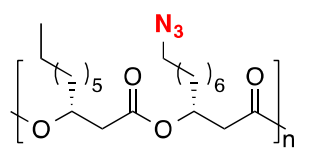

PHODN $_{3}$

\begin{tabular}{|c|c|c|c|c|}
\hline $\begin{array}{l}\text { Substrate mol ratio } \\
\left(\mathrm{C} 8: \mathrm{C}_{10 N_{3}}\right)\end{array}$ & $\begin{array}{l}\text { CDW } \\
\left(g^{-1}\right)\end{array}$ & $\begin{array}{l}\text { PHA yield }^{\mathrm{a}} \\
\text { (mass \%) }^{\text {mass }}\end{array}$ & $\begin{array}{c}\text { PHA/CDW ratio } \\
\text { (mass \%) }\end{array}$ & $\begin{array}{c}\text { Polymer mol ratio } \\
\left(\mathrm{C} 8: \mathrm{C}^{10 N_{3}}\right)\end{array}$ \\
\hline $1: 0.020$ & $1.29 \pm 0.01$ & $17.6 \pm 3.7$ & $20.0 \pm 4.1$ & $1: 0.048 \pm 0.003$ \\
\hline $1: 0.053$ & $1.12 \pm 0.02$ & $16.0 \pm 0.9$ & $21.1 \pm 1.2$ & $1: 0.118 \pm 0.003$ \\
\hline $1: 0.111$ & $1.04 \pm 0.01$ & $12.0 \pm 1.6$ & $17.4 \pm 2.5$ & $1: 0.235 \pm 0.005$ \\
\hline $1: 0.250$ & $1.21 \pm 0.02$ & $15.2 \pm 3.0$ & $19.9 \pm 4.1$ & $1: 0.470 \pm 0.013$ \\
\hline
\end{tabular}

${ }^{\mathrm{a}}$ Based on theoretical conversion of fatty acids to polymer. ${ }^{\mathrm{b}}$ Ratio of polymer produced and CDW.

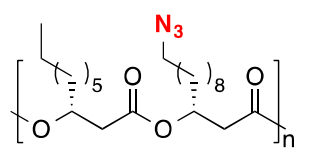

PHODDN $_{3}$

\begin{tabular}{|c|c|c|c|c|}
\hline $\begin{array}{l}\text { Substrate mol ratio } \\
\left(\mathrm{C} 8: \mathrm{C}_{10 \mathrm{~N}_{3}}\right)\end{array}$ & $\begin{array}{l}\text { CDW } \\
\left(g^{-1}\right)\end{array}$ & $\begin{array}{l}\text { PHA yield }^{a} \\
\text { (mass \%) }^{\text {mass }}\end{array}$ & $\begin{array}{c}\text { PHA/CDW ratio } \\
\text { (mass \%) }\end{array}$ & $\begin{array}{l}\text { Polymer mol ratio } \\
\left(\mathrm{C} 8: \mathrm{C12N}_{3}\right)\end{array}$ \\
\hline $1: 0.020$ & $1.05 \pm 0.07$ & $18.8 \pm 3.0$ & $26.4 \pm 5.4$ & $1: 0.080 \pm 0.010$ \\
\hline $1: 0.053$ & $0.98 \pm 0.03$ & $15.6 \pm 1.9$ & $23.8 \pm 3.4$ & $1: 0.248 \pm 0.015$ \\
\hline $1: 0.111$ & $1.16 \pm 0.04$ & $19.9 \pm 0.9$ & $26.5 \pm 0.6$ & $1: 0.515 \pm 0.023$ \\
\hline $1: 0.250$ & $1.10 \pm 0.14$ & $19.3 \pm 1.8$ & $28.6 \pm 0.9$ & $1: 1.952 \pm 0.170$ \\
\hline
\end{tabular}




\section{GPC Results}
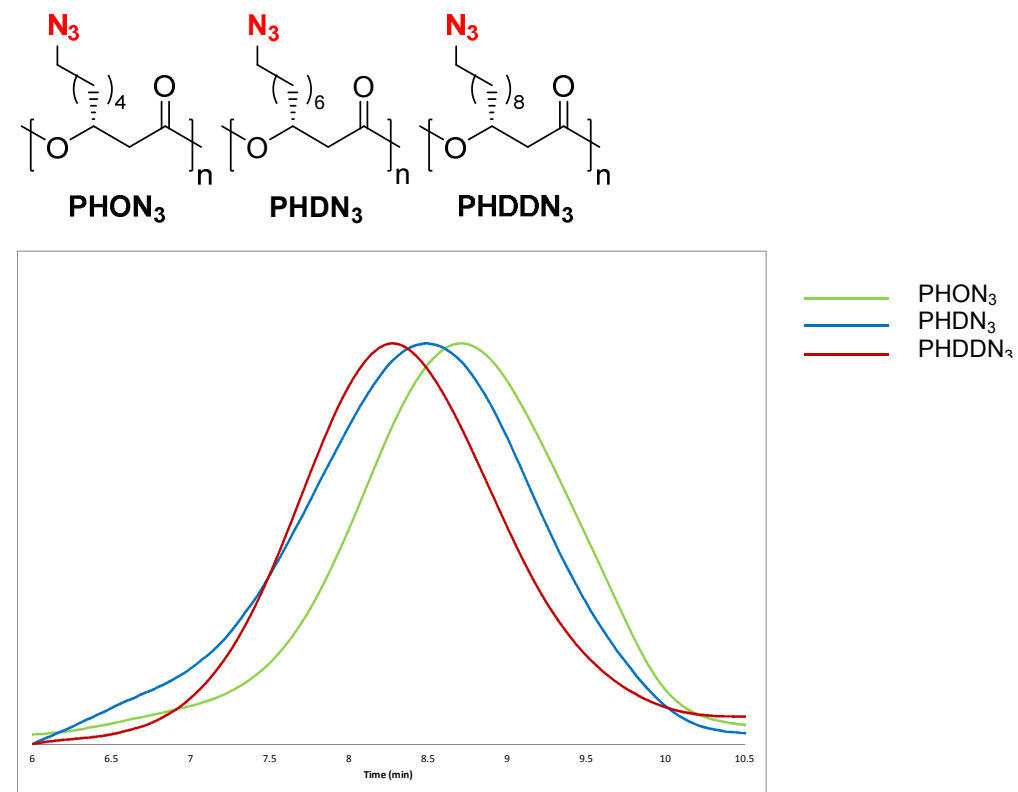

\begin{tabular}{cc}
\hline Homopolymer & $\boldsymbol{M}_{\mathbf{n}}$ (kDa) (PDI) \\
\hline $\mathrm{PHON}_{3}$ & $34(2.6)$ \\
$\mathrm{PHDN}_{3}$ & $47(3.6)$ \\
$\mathrm{PHDDN}_{3}$ & $126(2.1)$
\end{tabular}
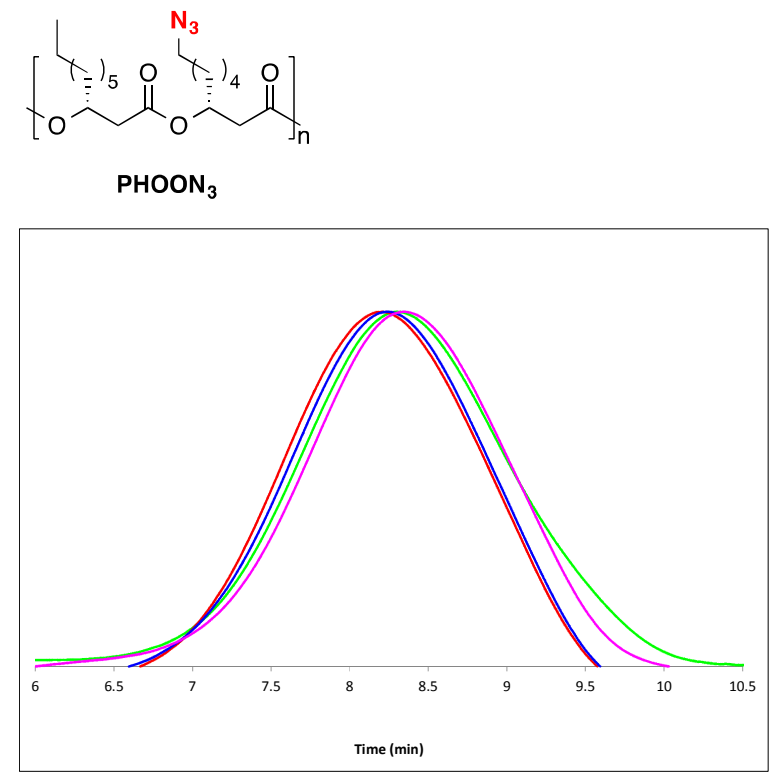

$1: 0.022 \mathrm{C} 8: \mathrm{C}^{2} \mathrm{~N}_{3}$

$1: 0.058 \quad \mathrm{C} 8: \mathrm{C}^{-} \mathrm{N}_{3}$

\begin{tabular}{cc}
\hline $\begin{array}{c}\text { Polymer mol ratio } \\
\left(\mathbf{C 8}: \mathbf{C 8 N}_{\mathbf{3}}\right)\end{array}$ & $\boldsymbol{M}_{\mathbf{n}}(\mathbf{k D a})(\mathrm{PDI})$ \\
\hline $1: 0.022 \pm 0.003$ & $66 \pm 3(2.1 \pm 0.1)$ \\
$1: 0.058 \pm 0.010$ & $74 \pm 4(1.9 \pm 0.1)$ \\
$1: 0.138 \pm 0.008$ & $64 \pm 3(2.0 \pm 0.1)$ \\
$1: 0.280 \pm 0.022$ & $57 \pm 2(1.9 \pm 0.2)$
\end{tabular}




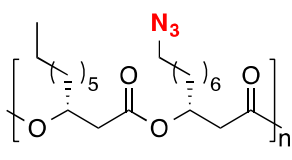

PHODN $_{3}$

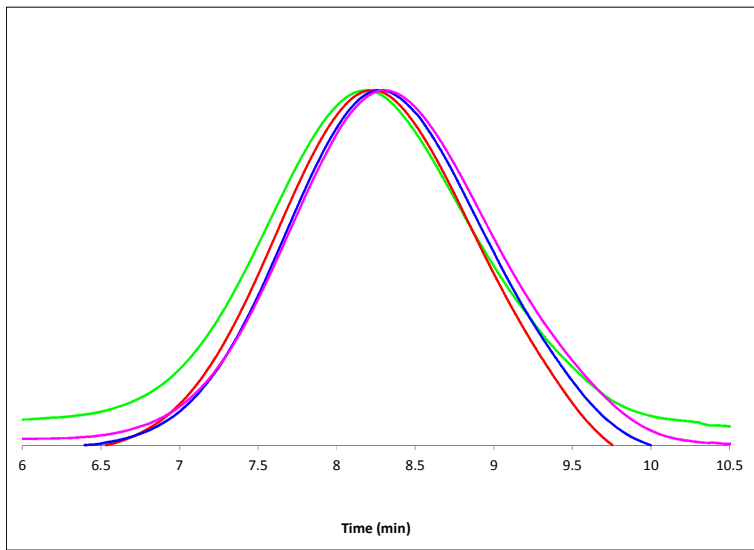

Polymer mol ratio

(C8: $\mathbf{C 1 0 N}_{3}$ )

$1: 0.048 \pm 0.003 \quad 67 \pm 1(2.2 \pm 0.1)$

$1: 0.118 \pm 0.003 \quad 63 \pm 2(2.3 \pm 0.1)$

$1: 0.235 \pm 0.005 \quad 60 \pm 2(2.2 \pm 0.1)$

$1: 0.470 \pm 0.013 \quad 55 \pm 3(2.2 \pm 0.1)$

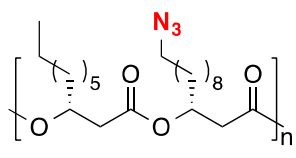

PHODDN $_{3}$

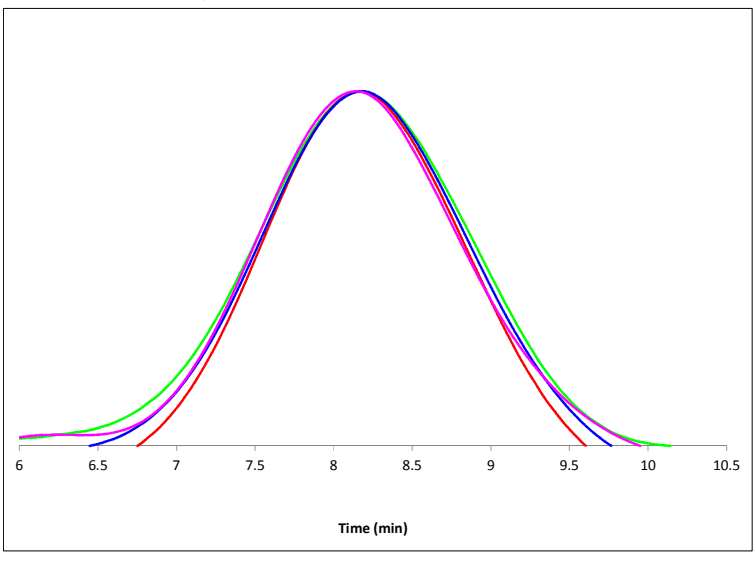

Polymer mol ratio

(C8: $\mathbf{C 1 2 N}_{3}$ )

$1: 0.080 \pm 0.010 \quad 69 \pm 2(2.1 \pm 0.1)$

$1: 0.248 \pm 0.015 \quad 71 \pm 6(2.2 \pm 0.2)$

$1: 0.515 \pm 0.023 \quad 66 \pm 1(2.2 \pm 0.1)$

$1: 1.952 \pm 0.170 \quad 70 \pm 3(2.2 \pm 0.1)$ $+\quad 1: 0.048 \quad \mathrm{C} 8: \mathrm{C}_{10 N_{3}}$ $1: 0.118 \mathrm{C} 8: \mathrm{C}^{10 N_{3}}$ $1: 0.235 \mathrm{C} 8: \mathrm{C}_{10 \mathrm{~N}_{3}}$ $1: 0.470 \quad \mathrm{C} 8: \mathrm{C}_{10 N_{3}}$ 


\section{FT-IR Spectra}

$\mathrm{N}_{3}$

\rangle$_{I_{4}}$<smiles>C=C(C)CCOC</smiles>

$\mathrm{PHON}_{3}$

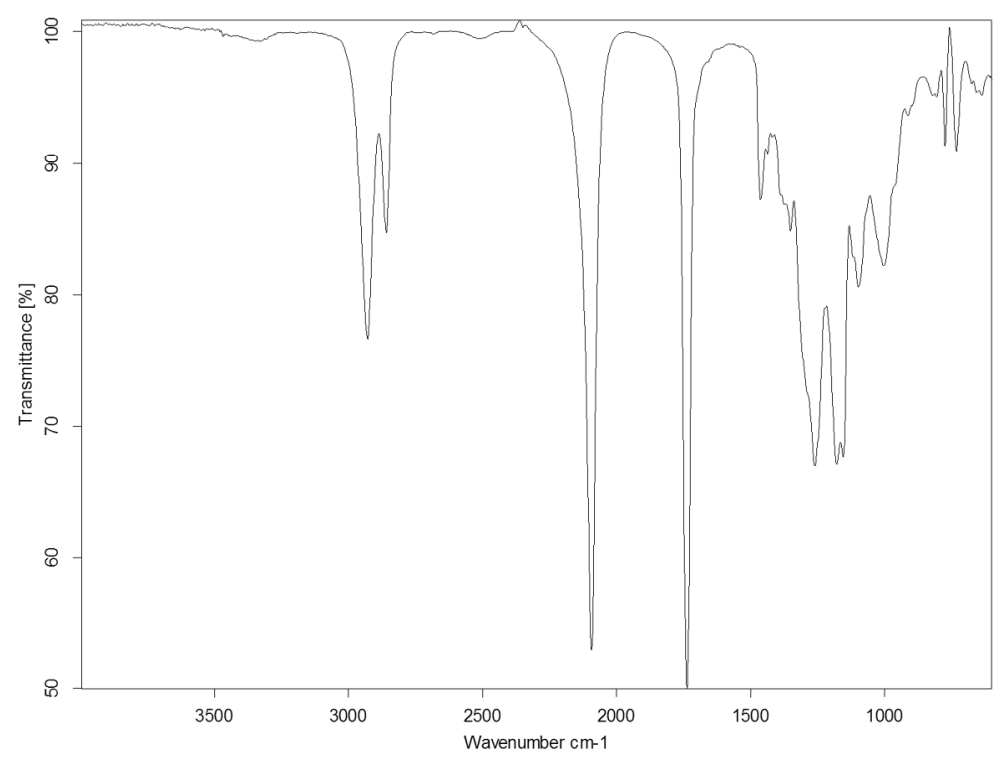

$\mathrm{N}_{3}$

$\overbrace{I_{6}} \mathrm{O}$

次

$\mathrm{PHDN}_{3}$

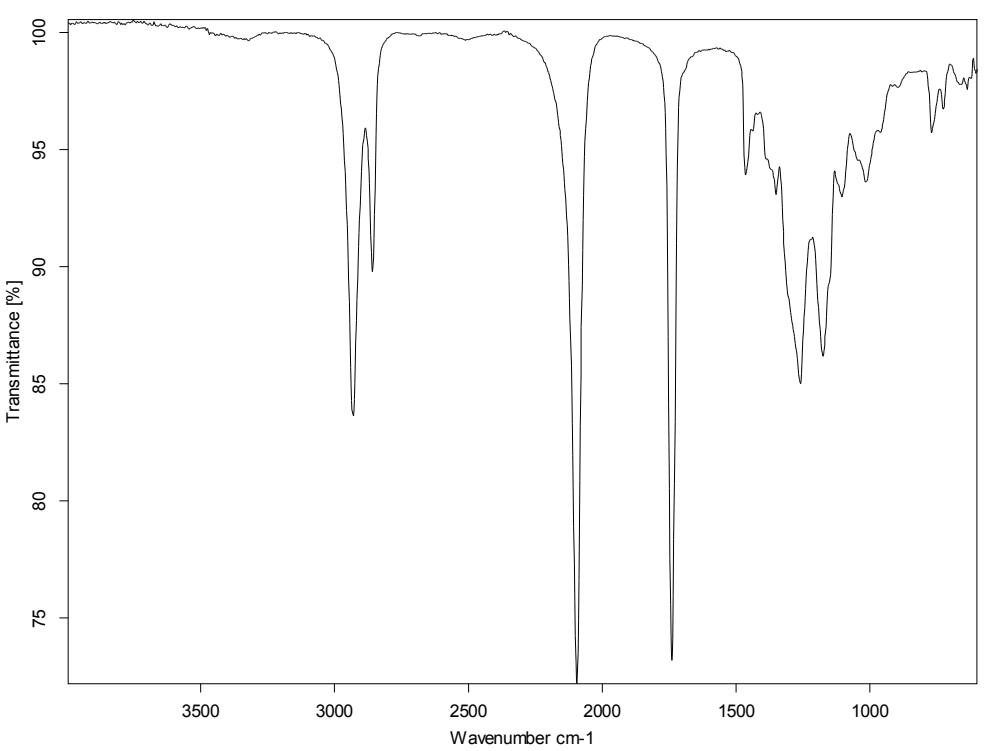


$\mathrm{N}_{3}$

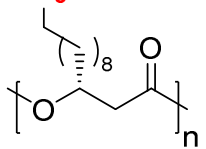

PHDDN $_{3}$
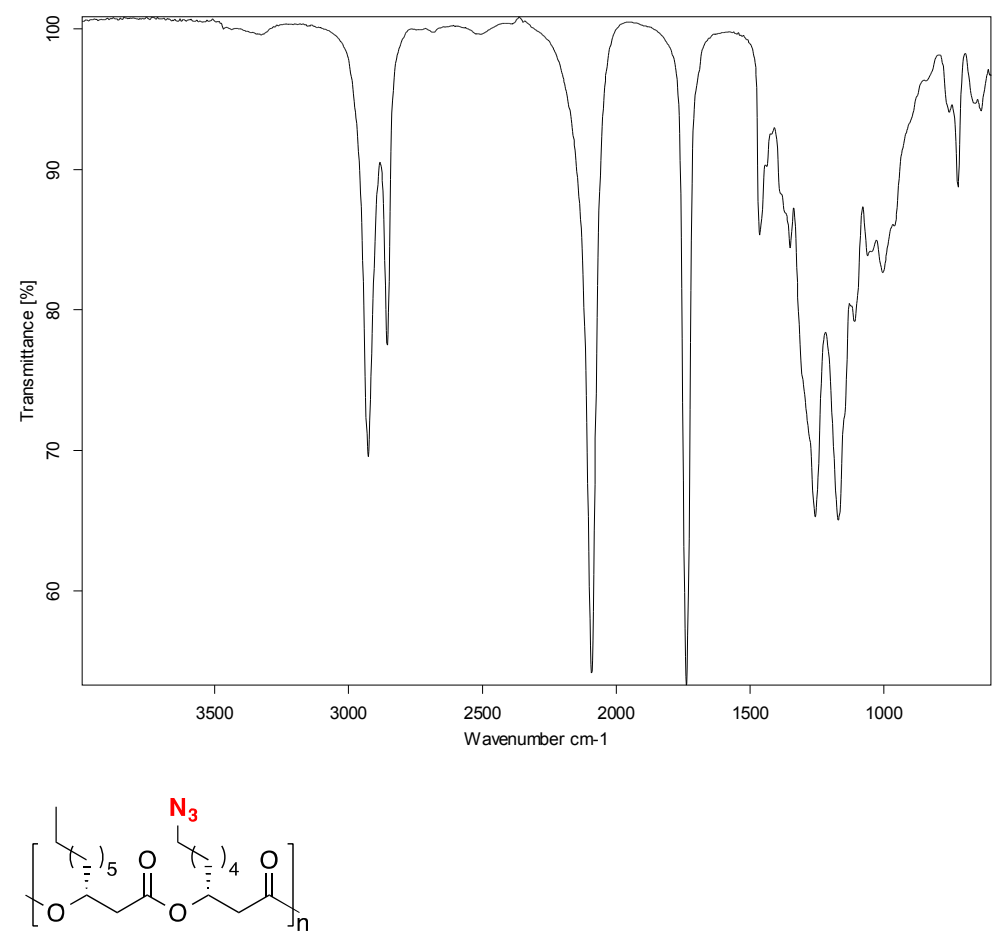

$\mathrm{PHOON}_{3}$

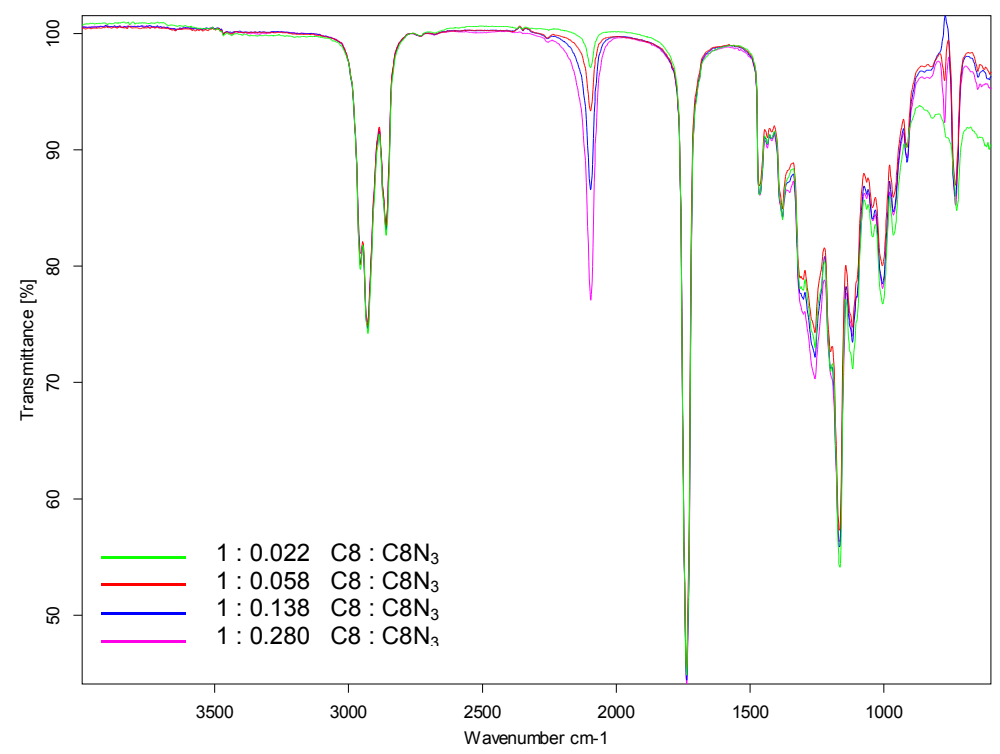


$\underbrace{\left.C_{0}\right)_{5}}_{0}$

PHODN $_{3}$

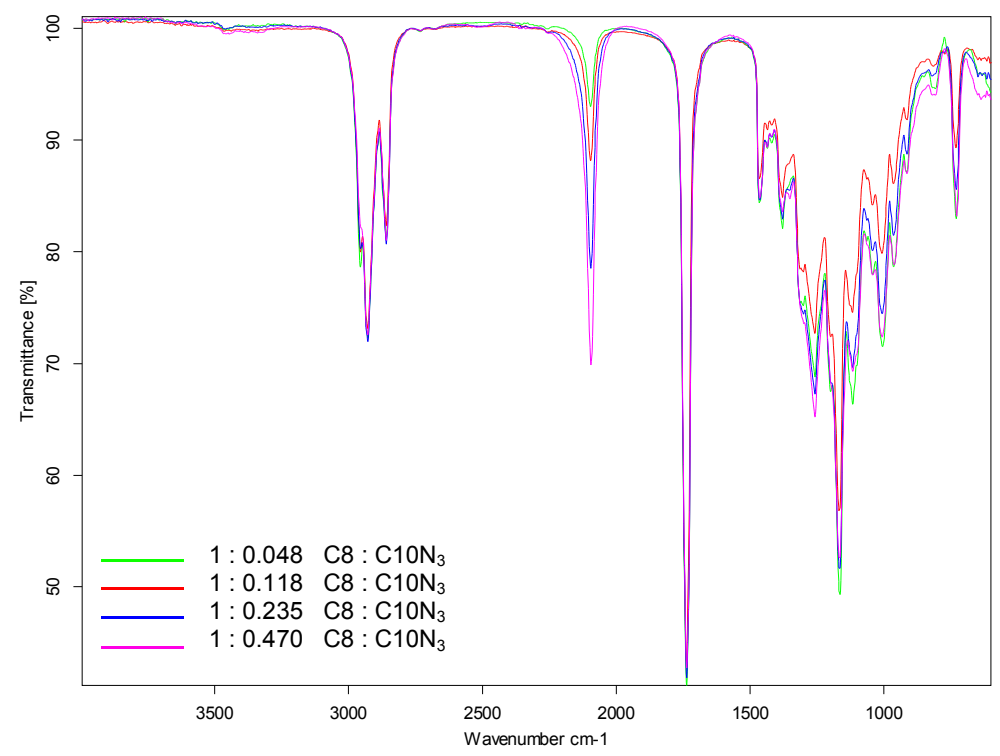

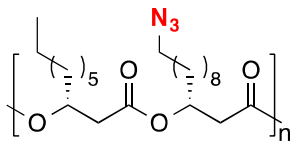

PHODDN $_{3}$

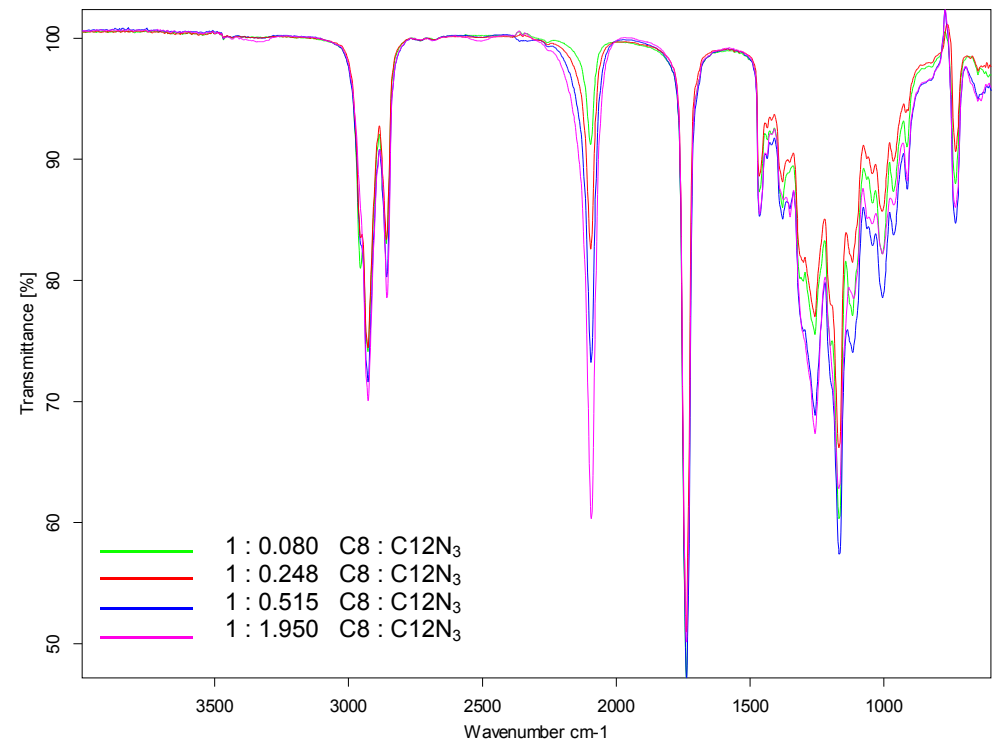




\section{Thermal Properties}

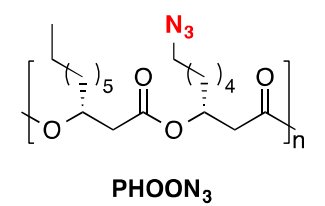

\begin{tabular}{cccccc}
\hline $\begin{array}{c}\text { Polymer mol ratio } \\
\left.\text { (C8 : C8N } \mathbf{C}_{3}\right)\end{array}$ & $\boldsymbol{T}_{\mathrm{d} 1}\left({ }^{\circ} \mathbf{C}\right)$ & $\boldsymbol{T}_{\mathrm{d} 2}\left({ }^{\circ} \mathbf{C}\right)$ & $\boldsymbol{T}_{\mathrm{g}}\left({ }^{\circ} \mathbf{C}\right)$ & $\boldsymbol{T}_{\mathrm{c}}\left({ }^{\circ} \mathrm{C}\right)$ & $\boldsymbol{T}_{\mathrm{m}}\left({ }^{\circ} \mathbf{C}\right)$ \\
\hline $1: 0.022 \pm 0.003$ & $266.8 \pm 6.2$ & $434.7 \pm 7.4$ & $-41.8 \pm 0.1$ & n.d. & n.d. \\
$1: 0.058 \pm 0.010$ & $269.2 \pm 3.1$ & $445.5 \pm 6.7$ & $-41.8 \pm 0.3$ & n.d. & n.d. \\
$1: 0.138 \pm 0.008$ & $258.4 \pm 2.6$ & $454.6 \pm 3.5$ & $-42.2 \pm 0.1$ & n.d. & n.d. \\
$1: 0.280 \pm 0.022$ & $246.6 \pm 1.9$ & $457.3 \pm 0.5$ & $-42.3 \pm 0.6$ & n.d. & n.d.
\end{tabular}

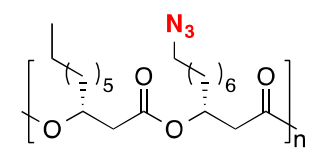

PHODN $_{3}$

\begin{tabular}{|c|c|c|c|c|c|}
\hline $\begin{array}{l}\text { Polymer mol ratio } \\
\left(\mathrm{C8}: \mathrm{C10N}_{3}\right)\end{array}$ & $T_{\mathrm{d} 1}\left({ }^{\circ} \mathrm{C}\right)$ & $T_{\mathrm{d} 2}\left({ }^{\circ} \mathrm{C}\right)$ & $T_{\mathrm{g}}\left({ }^{\circ} \mathrm{C}\right)$ & $T_{\mathrm{c}}\left({ }^{\circ} \mathrm{C}\right)$ & $T_{m}\left({ }^{\circ} \mathrm{C}\right)$ \\
\hline $1: 0.048 \pm 0.003$ & $264.7 \pm 5.8$ & $460.3 \pm 22.5$ & $-42.1 \pm 0.6$ & n.d. & n.d. \\
\hline $1: 0.118 \pm 0.003$ & $252.5 \pm 7.1$ & $457.9 \pm 4.9$ & $-43.8 \pm 0.2$ & n.d. & n.d. \\
\hline $1: 0.235 \pm 0.005$ & $240.1 \pm 7.1$ & $464.5 \pm 9.4$ & $-45.4 \pm 1.3$ & n.d. & n.d. \\
\hline $1: 0.470 \pm 0.013$ & $244.3 \pm 2.3$ & $465.2 \pm 9.7$ & $-47.3 \pm 0.7$ & n.d. & n.d. \\
\hline PHODDN $_{3}$ & & & & & \\
\hline $\begin{array}{l}\text { Polymer mol ratio } \\
\left(\mathrm{C} 8: \mathrm{C12N}_{3}\right)\end{array}$ & $T_{\mathrm{d} 1}\left({ }^{\circ} \mathrm{C}\right)$ & $T_{\mathrm{d} 2}\left({ }^{\circ} \mathrm{C}\right)$ & $T_{\mathrm{g}}\left({ }^{\circ} \mathrm{C}\right)$ & $T_{\mathrm{c}}\left({ }^{\circ} \mathrm{C}\right)$ & $T_{\mathrm{m}}\left({ }^{\circ} \mathrm{C}\right)$ \\
\hline $1: 0.080 \pm 0.010$ & $263.2 \pm 3.9$ & $463.0 \pm 0.9$ & $-43.7 \pm 0.4$ & n.d. & n.d. \\
\hline $1: 0.248 \pm 0.015$ & $252.0 \pm 0.5$ & $467.5 \pm 0.9$ & $-48.2 \pm 0.6$ & n.d. & n.d. \\
\hline $1: 0.515 \pm 0.023$ & $243.3 \pm 1.4$ & $471.3 \pm 1.4$ & $-52.5 \pm 0.2$ & n.d. & n.d. \\
\hline $1: 1.952 \pm 0.170$ & $238.6 \pm 0.5$ & $474.0 \pm 1.4$ & $-56.7 \pm 0.7$ & n.d. & n.d. \\
\hline
\end{tabular}




\section{DSC Thermograms}

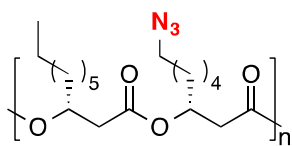

$\mathrm{PHOON}_{3}$
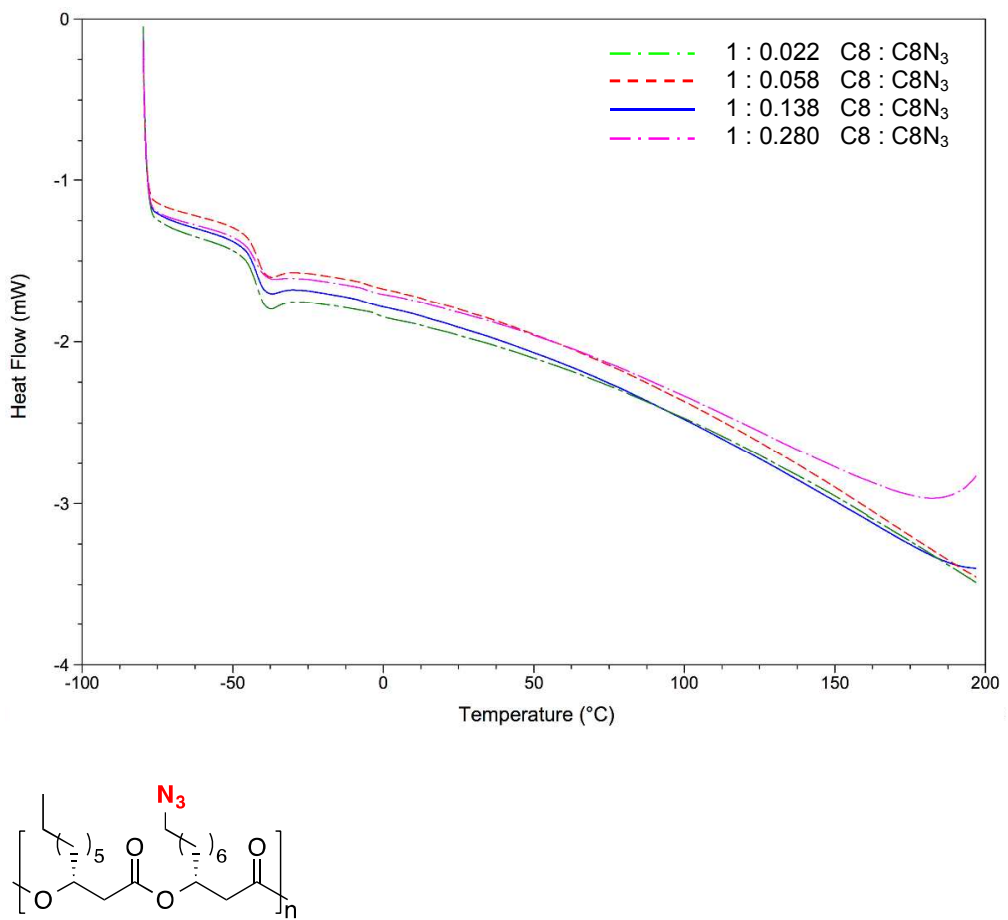

$\mathrm{PHODN}_{3}$

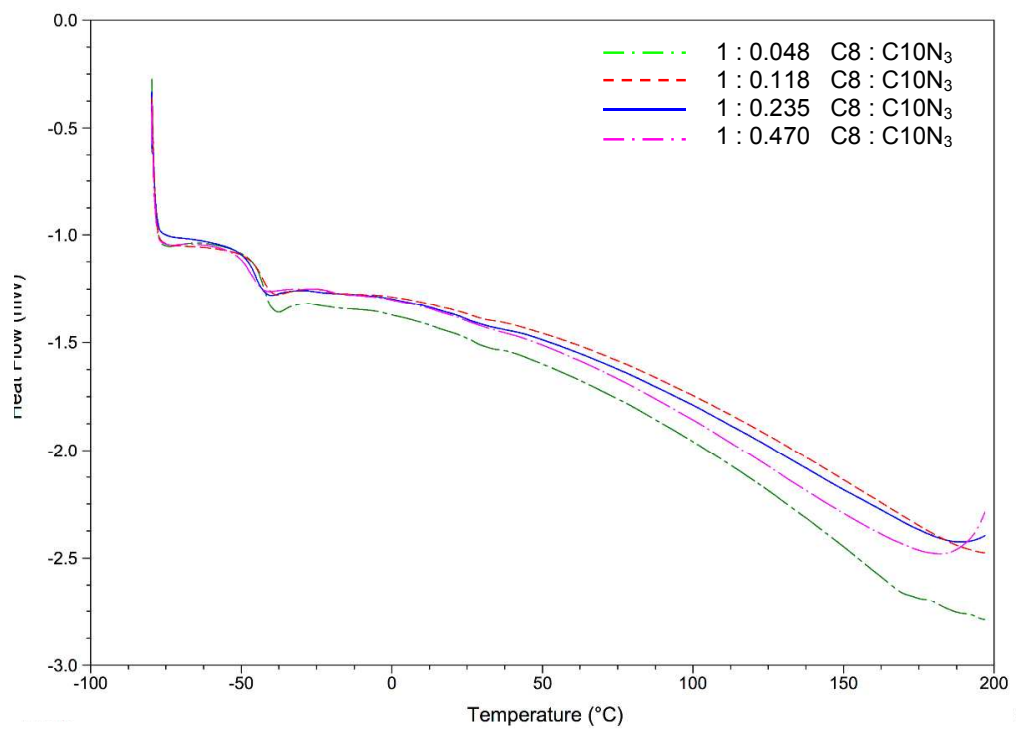


$\mathrm{L}_{0} \overbrace{0}^{L_{1}}$

PHODDN $_{3}$

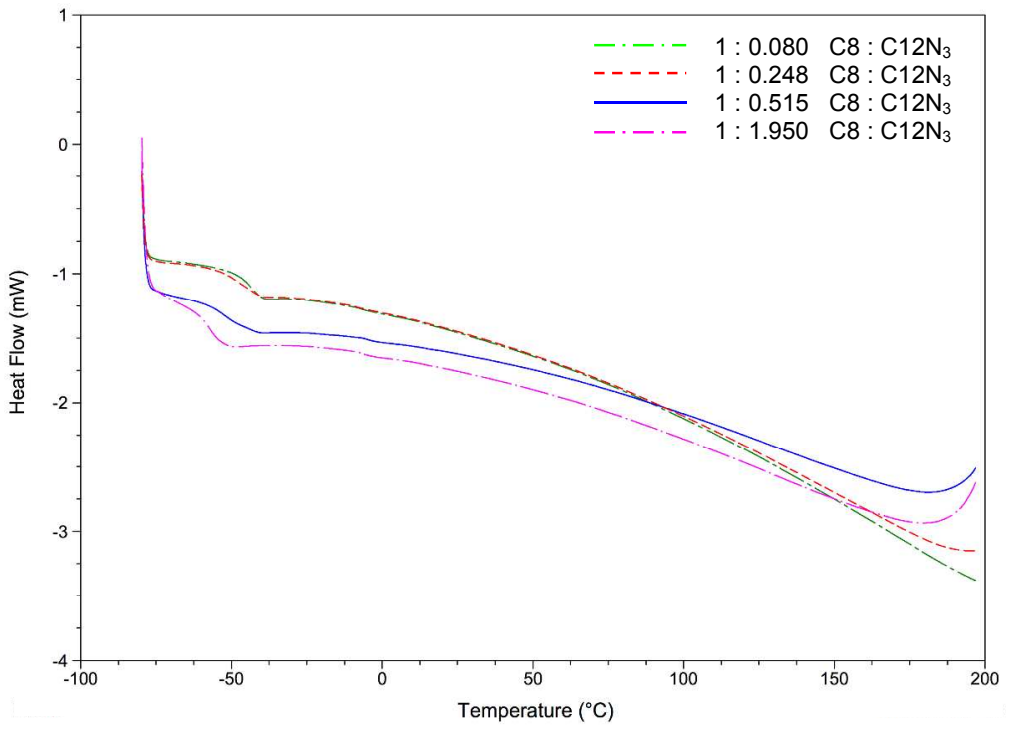




\section{TGA Thermograms}

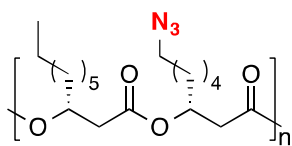

$\mathrm{PHOON}_{3}$
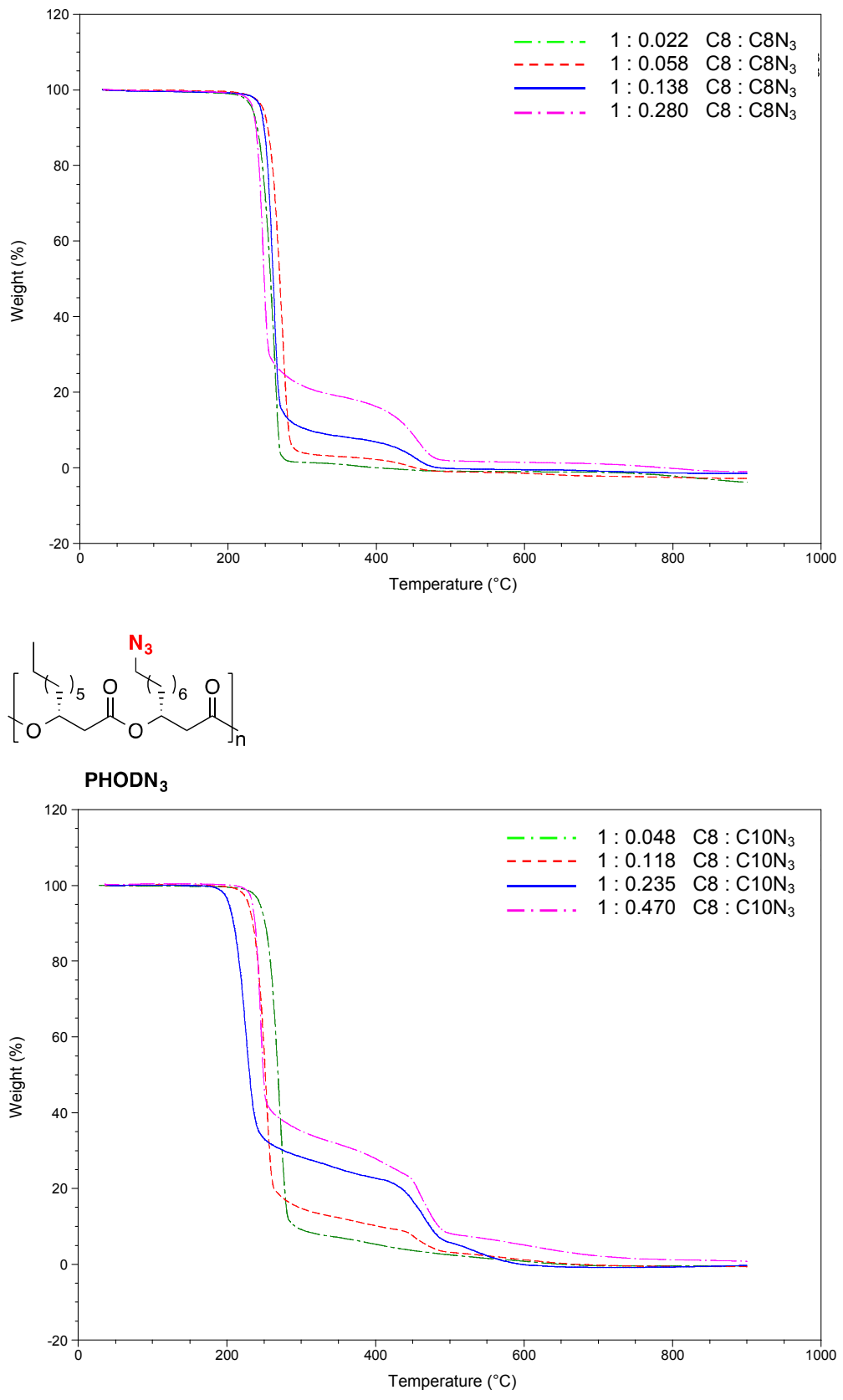


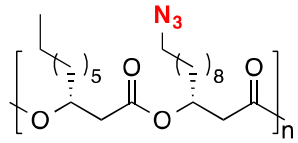

PHODDN $_{3}$

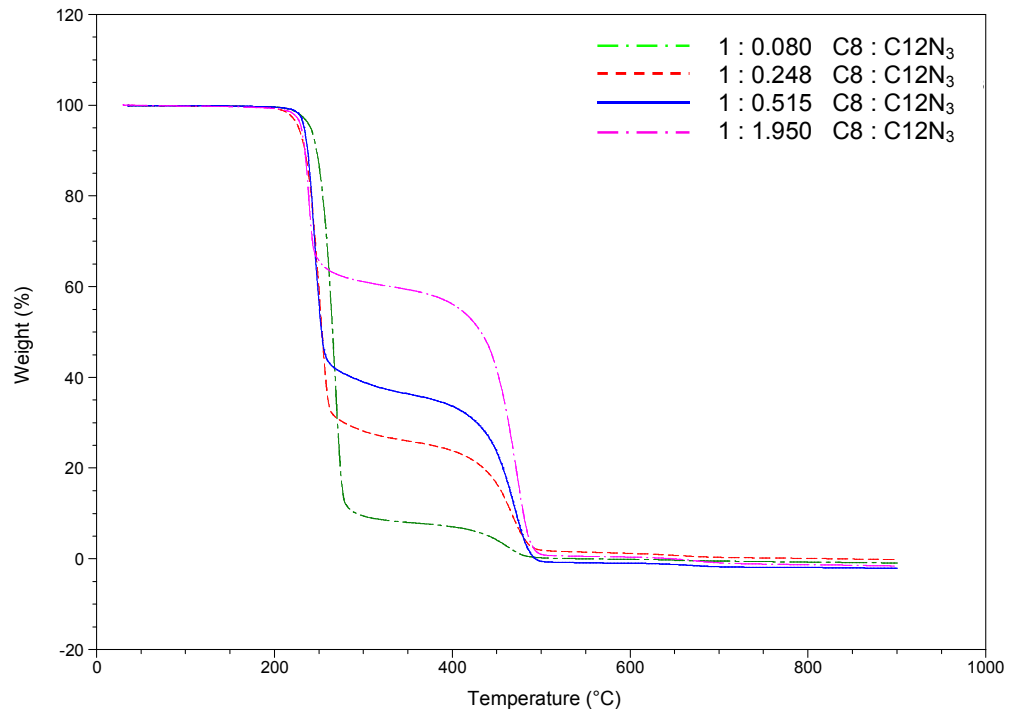

